\title{
Assembly of the Annieopsquotch Accretionary Tract, Newfoundland Appalachians: Age and Geodynamic Constraints from Syn-Kinematic Intrusions
}

\author{
C. Johan Lissenberg, Alexandre Zagorevski, Vicki J. McNicoll, ${ }^{1}$ \\ Cees R. van Staal, ${ }^{1}$ and Joseph B. Whalen ${ }^{1}$ \\ Department of Earth Sciences, University of Ottawa, and Ottawa-Carleton Geoscience Centre, \\ 140 Louis Pasteur, Ottawa, Ontario K1N 6N5, Canada \\ (e-mail: johan.lissenberg@science.uottawa.ca)
}

\begin{abstract}
A B S T R A C T
The Annieopsquotch Accretionary Tract (AAT) comprises several ophiolites and arc-back-arc igneous complexes that were accreted to the Dashwoods microcontinent during the Ordovician Taconic orogeny. The Lloyds River Fault Zone, which separates the AAT from the Dashwoods microcontinent, yielded ${ }^{40} \mathrm{Ar} /{ }^{39} \mathrm{Ar}$ hornblende ages of ca. 470 Ma. The fault zone was intruded syn-kinematically by the shoshonitic Portage Lake monzogabbro and the Pierre's Pond suite, which gave $\mathrm{U} / \mathrm{Pb}$ zircon ages of $462 \pm 2 \mathrm{Ma}$ plus $464 \pm 2 \mathrm{Ma}$ and $459 \pm 3 \mathrm{Ma}$, respectively. The Otter Pond granodiorite intruded syn-kinematically into the Otter Brook Shear Zone, which separates the Annieopsquotch ophiolite belt from the structurally underlying ophiolitic Lloyds River Complex. It yielded a U/Pb zircon age of $468 \pm 2 \mathrm{Ma}$. The Buchans arc and its continental basement were accreted to the Lloyds River Complex prior to 468 Ma. Syn-kinematic plutons have arc affinity, with $\varepsilon_{\mathrm{Nd}}$ ranging between -0.9 and -6.8 , and are coeval with the adjacent Notre Dame Arc. Our data thus suggest the majority of the AAT was accreted to the Dashwoods microcontinent by $468 \mathrm{Ma}$, when consanguineous, dominantly arclike plutons intruded within the AAT and adjacent Notre Dame Arc. The Portage Lake monzogabbro and Otter Pond mafic suite are more mafic than Notre Dame Arc plutons of similar age because of their intrusion into the thin, mafic crust of the AAT and ascent along shear zones. Our data indicate the formation and subsequent accretion of ophiolites and arc-back-arc complexes occurred within a very short time span (5-10 Ma). The sources of AAT syn-orogenic magmatism are diverse and include melting of subarc mantle during slab breakoff, lithospheric mantle, and lower crust. The Ordovician Appalachian margin of Laurentia grew by the accretion of oceanic terranes and intrusion of mantle-derived magma. Recycling of continental crust by rifting and subsequent collision played an important part of the tectonic evolution of the AAT.
\end{abstract}

Online enhancements: appendix, tables.

\section{Introduction}

The Annieopsquotch Accretionary Tract (AAT) is a well-preserved Ordovician accretionary complex that occurs along the fundamental suture formed by the Ordovician-Silurian closure of the Iapetus Ocean, the Red Indian Line (Williams et al. 1988; van Staal et al. 1998). It comprises several faultbounded, west-dipping slices of dominantly mafic arc-back-arc complexes and ophiolites that formed in the upper plate above a west-dipping subducting 2005.

Manuscript received October 28, 2004; accepted March 22,

${ }^{1}$ Geological Survey of Canada, Natural Resources Canada, 601 Booth Street, Ottawa, Ontario K1A 0E8, Canada. slab and have been transferred from their original intraoceanic setting to the peri-Laurentian Dashwoods microcontinent by underplating (van Staal et al. 1998; Lissenberg et al., forthcoming $a$ ). Detailed mapping, in collaboration with extensive geochemistry and high-precision U-Pb and ${ }^{40} \mathrm{Ar} /$ ${ }^{39} \mathrm{Ar}$ geochronology, has provided a tightly constrained geological framework for the AAT, making it one of the best-documented examples of an Early Paleozoic accretionary complex. The AAT thus provides a unique opportunity to study the processes involved in accretionary tectonics and to evaluate the differences and similarities between Paleozoic 
and Mesozoic-Cenozoic accretionary orogeny. Of particular interest are the relative contributions of oceanic material and recycled continental crust and the sources involved in magmatism in accretionary tracts. These issues remain a subject of intense research and debate, particularly because of the role accretionary complexes play in continental growth (e.g., Sengör and Natal'in 1996; Xiao et al. 2003).

In this article, we describe the results of ${ }^{40} \mathrm{Ar} /{ }^{39} \mathrm{Ar}$ geochronology of the shear zones that separate different units of the AAT and $\mathrm{U} / \mathrm{Pb}$ geochronology and geochemistry of the plutons that intrude these shear zones. These data provide age constraints on juxtaposition of the different components of the AAT and constrain the geodynamic evolution of the AAT. Linking the tectonic and magmatic events of the AAT with those that took place in the adjacent Dashwoods microcontinent provides constraints on the overall tectonic evolution of the peri-Laurentian portion of the Newfoundland Appalachians during the Early to Late Ordovician Taconic orogeny (Williams and Hatcher 1983). We will demonstrate that (1) the majority of the AAT was accreted to Dashwoods by $468 \mathrm{Ma}$, indicating that accretion occurred within 5-10 Ma after formation of the units; (2) the AAT comprises an important component of recycled continental crust in addition to accreted oceanic crust, and sediments are notably absent; and (3) plutons intruding the AAT tapped variable sources (sub-arc mantle, lithospheric mantle, crust). Magmatism is related to the adjacent Notre Dame Arc but is chemically more primitive owing to intrusion into thin, predominantly mafic crust of the AAT and ascent along shear zones.

\section{Regional Geology}

The Newfoundland Appalachians mainly formed as a result of the closure of the Iapetus Ocean, which juxtaposed Laurentia with several peri-Gondwanan continental blocks. Rocks formed within the oceanic realm of Iapetus are preserved in Newfoundland's Dunnage Zone (Williams 1979). The Dunnage Zone has been subdivided into the peri-Laurentian Notre Dame and Dashwoods Subzones and the Exploits Subzone, which mainly has a peri-Gondwanan provenance (Williams et al. 1988; Williams 1995; fig. 1). The Notre Dame and Dashwoods Subzones are separated from periGondwanan rocks of the Exploits Subzone by the Red Indian Line (Williams et al. 1988; van Staal et al. 1998). Both the Notre Dame and Dashwoods Subzones are dominated by granitoid arc plutons and associated volcanic rocks of the Notre Dame
Arc (e.g., Whalen et al. 1987, 1997), ophiolites, and dominantly mafic arc-back-arc complexes. Magmatism in the Notre Dame Arc was episodic, with major pulses in the Tremadoc, Llanvirn-Caradoc, and Ashgill-Wenlock (van Staal et al. 2003; Whalen et al. 2003). Ophiolites occur in three distinct belts: the Lush's Bight and Baie Verte oceanic tracts, which overlie metasedimentary rocks of the Notre Dame and Humber (sub)zones, respectively (e.g., Swinden et al. 1997), and the Annieopsquotch ophiolite belt (Lissenberg et al., forthcoming $a$ ). The Annieopsquotch ophiolite belt, along with most mafic arc-back-arc complexes, occurs in a linear belt along the eastern margin of the Notre Dame Subzone. Together, these rocks are referred to as the Annieopsquotch Accretionary Tract (AAT; van Staal et al. 1998). The Dashwoods Subzone generally exposes a deeper crustal level than the Notre Dame Subzone and has a larger sedimentary component (e.g., the amphibolite-granulite facies Cormacks Lake Complex; Pehrsson et al. 2003), but both share a common Ordovician tectonic history (Pehrsson et al. 2003).

It has been inferred on the basis of isotopic and geochronological studies (e.g., Swinden et al. 1997; Whalen et al. 1997), combined with tectonic relationships, that both the Dashwoods and Notre Dame Subzones are underlain by thinned continental crust, which is interpreted as a ribbonshaped microcontinent, referred to as Dashwoods, that rifted off of the Laurentian margin during the Early Cambrian (Waldron and van Staal 2001). During the Cambrian to Early Ordovician, the Dashwoods microcontinent was separated from Laurentia by the Humber Seaway. The Humber Seaway was closed by east-directed subduction underneath the Dashwoods microcontinent in the Tremadoc, leading to the first Tremadoc magmatic phase of the Notre Dame Arc, and ended with the collision between Laurentia and the Dashwoods microcontinent by at least $475 \mathrm{Ma}$ (Waldron and van Staal 2001). This collision resulted in slab break-off of the oceanic portion of the Laurentian slab, generating the second pulse of Notre Dame Arc magmatism (van Staal et al. 2003; Whalen et al. 2003), and initiated convergence to the east (i.e., outboard) of the Dashwoods microcontinent, leading to the formation of a west-dipping subduction zone that was responsible for formation of the units now preserved within the AAT (Lissenberg et al., forthcoming $a$ ).

\section{The Annieopsquotch Accretionary Tract}

The AAT is the easternmost unit of the Notre Dame Subzone and is defined as a complex east- 


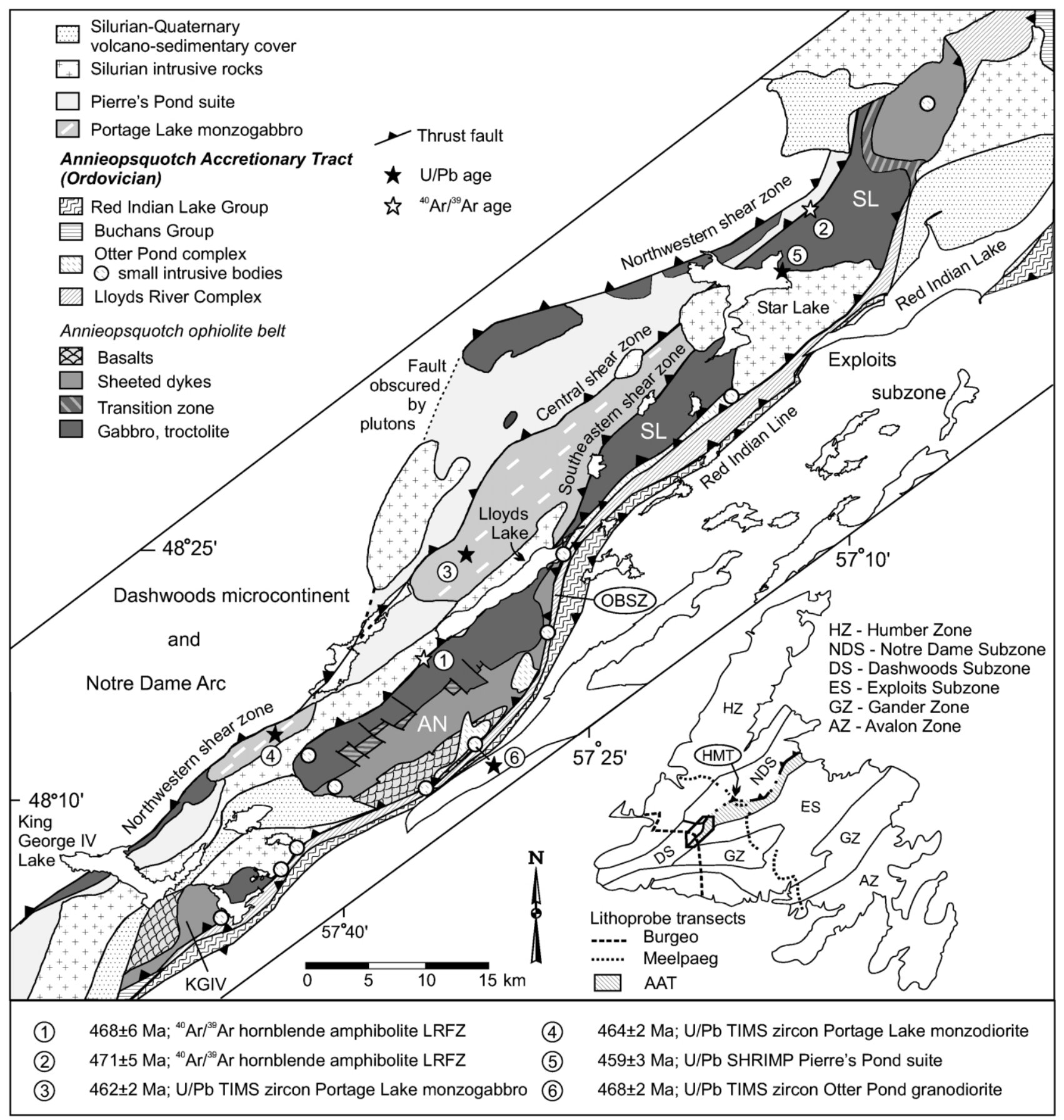

Figure 1. Simplified geological map of the Annieopsquotch Accretionary Tract $(A A T)$, with approximate locations of samples dated in this study indicated by numbered filled stars $(\mathrm{U} / \mathrm{Pb})$ and open stars $\left({ }^{40} \mathrm{Ar} /{ }^{39} \mathrm{Ar}\right)$. Inset shows tectonostratigraphic zones of the Newfoundland Appalachians, extent of the AAT, and the locations of the study, Lithoprobe seismic transects, and Hungry Mountain Thrust (HMT). AN = Annieopsquotch ophiolite; KGIV = King George IV ophiolite; $L R F Z=$ Lloyds River Fault Zone; OBSZ = Otter Brook shear zone; $S L=$ Star Lake ophiolite. Modified from Lissenberg et al. (forthcoming $b$ ) and van Staal et al. (forthcoming $a, b, c$ ). 

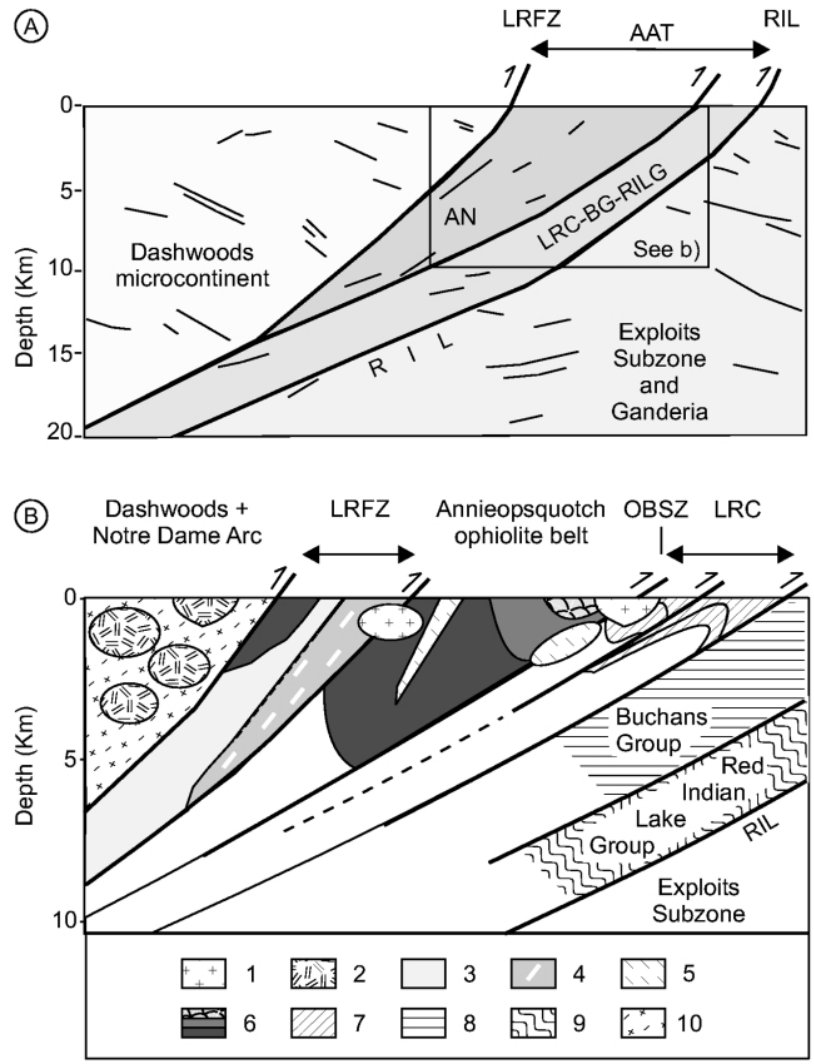

Figure 2. Schematic cross sections of the study area (no vertical exaggeration). $A$, Cross section based on lithoprobe seismic reflection profile along the Burgeo transect, modified from van der Velden et al. (2004). B, Schematic composite along strike cross section interpolated between Burgeo and Meelpaeg transects showing structural relationships and stratigraphy of different components of the Annieopsquotch Accretionary Tract $(A A T)$ as well as plutonic rocks described in this article. 1 = Silurian plutons (Lloyds Lake granite and Boogie Lake suite); 2 = Notre Dame Arc plutons; $3=$ Pierre's Pond suite; 4 = Portage Lake monzogabbro; $5=$ Otter Pond Complex; $6=$ Annieopsquotch ophiolite; $7=$ Lloyds River Complex; $8=$ Buchans Group; $9=$ Red Indian Lake Group; $10=$ Dashwoods. $A N=$ Annieopsquotch ophiolite; LRC-BG-RILG = Lloyds River Complex + Buchans Group + Red Indian Lake Group; $L R F Z=$ Lloyds River Fault Zone; OBSZ = Otter Brook Shear Zone; $R I L=$ Red Indian Line.

vergent thrust stack of ophiolites and arc-back-arc complexes that is bounded by the Lloyds River Fault Zone (LRFZ; Lissenberg and van Staal 2002) and Hungry Mountain Thrust to the west and by the Red Indian Line to the east (fig. 1; van Staal et al. 1998). Each thrust slice becomes progressively younger to the east (Thurlow et al. 1992; Zagorevski et al., forthcoming), suggesting sequential ac- cretion to the Dashwoods microcontinent (van Staal et al. 1998). Sedimentary rocks are scarce within the AAT, allowing detailed reconstruction of the relationships between the various mafic oceanic complexes. The different components of the AAT are mainly separated by northwest-dipping amphibolite- to sub-greenschist-grade shear zones, which in many places have been intruded by plutonic rocks during assembly of the tract. Most of these shear zones are thought to be Ordovician in age, although some of them accommodated out of sequence movement (e.g., Thurlow et al. 1992) or Silurian reactivation (Zagorevski and van Staal 2002). The AAT has a structural thickness varying from 8 to $15 \mathrm{~km}$ and comprises, from top to bottom, the Annieopsquotch ophiolite belt (Lissenberg et al., forthcoming $a$ ), the younger Lloyds River Complex ophiolitic sliver (defined below), the mature arc volcanic sequence of the Buchans Group (Swinden et al. 1997), and the younger immature arcback-arc succession of the Red Indian Lake Group (fig. 2; Zagorevski et al., forthcoming). In addition, it contains a suite of syn-kinematic plutonic and syn-orogenic volcanic and associated metasedimentary rocks, termed the Otter Pond Complex (figs. 1, 2; defined below). The limited structural thickness of the tract suggests parts of the units are currently missing. This likely resulted from strike-slip movements that accompanied accretion of the AAT (Lissenberg and van Staal 2002; Zagorevski and van Staal 2002) and possibly from subduction of some elements or parts thereof.

The Annieopsquotch ophiolite belt (481-478 Ma; Dunning and Krogh 1985) is defined as a band of ophiolite complexes and fragments that extends for ca. $200 \mathrm{~km}$ along the eastern margin of the Notre Dame Subzone (fig. 1; Lissenberg et al., forthcoming a). Its main components are the Annieopsquotch, Star Lake, and King George IV ophiolites, which lack the mantle section and lowermost crust but are otherwise intact (fig. 1). Correlative ophiolitic fragments occur along strike within the Hungry Mountain Complex (Whalen et al. 1997) and on the north coast of Newfoundland within the Hall Hill Complex (Bostock 1988). The ophiolite belt records early boninitic magmatism followed by a tholeiitic phase and is interpreted to have formed during initiation of west-directed subduction outboard of the Dashwoods microcontinent following the Dashwoods-Laurentia collision (Lissenberg et al., forthcoming a). The Annieopsquotch ophiolite belt is separated from the Dashwoods microcontinent by the LRFZ. The LFRZ is marked by highly strained amphibolites, separated by lenticular bodies of less deformed plutonic rocks, and comprises 
three major northwest-dipping shear zones (the northwestern, central, and southeastern shear zones; figs. 1, 2, 3A). The three shear zones are characterized by predominantly steeply northwestdipping foliations with moderately $\left(40^{\circ}-60^{\circ}\right)$ northto northeast-dipping lineations, and they record sinistral oblique underthrusting of the Annieopsquotch ophiolite belt beneath the Dashwoods microcontinent (Lissenberg and van Staal 2002). This is consistent with the sense of motion observed in amphibolite-facies mylonites that define the Hungry Mountain Thrust, the equivalent of the LRFZ immediately north of the town of Buchans (e.g., Calon and Green 1987).

The structurally underlying Lloyds River Complex is an ophiolitic sliver comprised of gabbro, anorthosite, sheeted dikes, and pillow lava, which are geochemically distinct from the Annieopsquotch ophiolite belt, and yielded an age of $473 \mathrm{Ma}$ (Zagorevski et al., forthcoming). It is interpreted to have originated in a back-arc basin to the Buchans arc (Zagorevski et al., forthcoming). The Lloyds River Complex is separated from the Annieopsquotch ophiolite belt by the Otter Brook Shear Zone (OBSZ; fig. 1). The OBSZ is a northwestdipping amphibolite to greenschist grade shear zone characterized by mylonite, mica schist, and phyllonite with strong northeast-trending foliations and north-northeast-plunging lineation (fig. 3B; Zagorevski and van Staal 2002). It records an important phase of sinistral oblique underthusting of the Lloyds River Complex beneath the An- nieopsquotch ophiolite belt (Zagorevski and van Staal 2002).

The Otter Pond Complex is defined herein as a distinct suite of plutonic rocks and associated highly deformed felsic volcanic and metasedimentary rocks, which is spatially associated with the OBSZ. The volcano-sedimentary rocks (rhyolite, amphibolite, garnet-mica schist, and graphitic schist) are contained within strands of the OBSZ, whereas the plutonic rocks intrude both within the shear zone and within surrounding units (fig. 1). The plutonic rocks of the Otter Pond Complex have been subdivided into a mafic suite-which comprises generally hornblende porphyritic to oikocrystic gabbros, diorites, and associated mafic dikes_-and a granodiorite suite. The mafic suite predominantly intrudes the Annieopsquotch ophiolite both as a ca. $2 \times 2-\mathrm{km}$ sized medium-grained pluton (fig. 1) and as meterwide (very) fine-grained dikes. Otter Pond mafic dikes have also been observed to intrude sheeted dikes of the Star Lake and King George IV ophiolites (fig. 1). The main body of the granodiorite suite intrudes the southeastern margin of the Annieopsquotch ophiolite, forming an elongate body (ca. $5 \times 0.7 \mathrm{~km}$ ) parallel to the OBSZ (fig. 1). In addition, the granodiorite suite occurs as meter-scale sheets intruding amphibolites of the OBSZ and as subordinate aphanitic, locally flow-banded dikes that intrude the Annieopsquotch ophiolite and Lloyds River Complex. The granodiorite is chemically similar to the aphanitic dikes and rhyolite of the volcano-sedimentary sequence (see below), suggest-

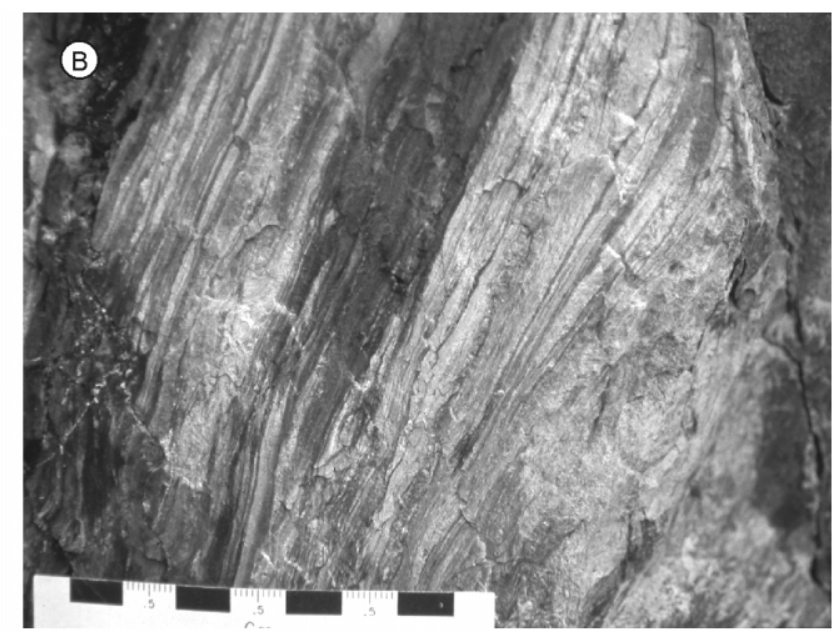

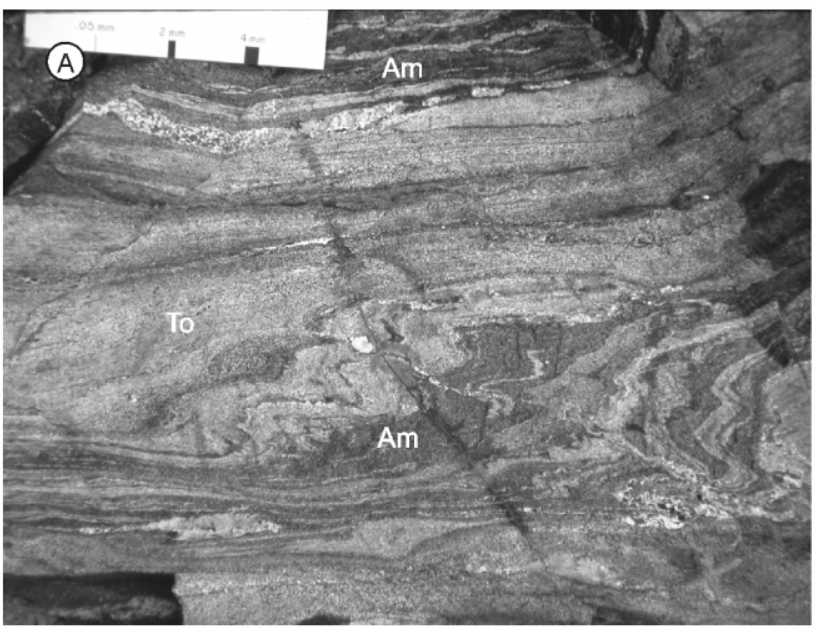

Figure 3. Field photographs illustrating the Lloyds River Fault Zone and Otter Brook Shear Zone. A, Highly strained tectonites of the Lloyds River Fault Zone composed of amphibolites $(A \mathrm{~m})$ and intrusive sheets of tonalite (To). Horizontal plane. $B$, Highly strained volcanic rocks of the Otter Pond Complex that mark the Otter Brook Shear Zone. View toward NE. Scale card divisions are $1 \mathrm{~cm}$. 
ing that together they form part of a consanguineous suite of shallow plutonic-volcanic bodies. These relationships suggest the Otter Pond Complex formed by intrusion and local extrusion and sedimentation along the OBSZ during thrusting of the Lloyds River Complex underneath the Annieopsquotch ophiolite belt.

The Lloyds River Complex is separated from the structurally underlying Buchans Group (473 Ma; Dunning et al. 1987) and Red Indian Lake Group (464 Ma; Zagorevski et al., forthcoming) by a series of southeast-directed ductile-brittle thrusts in the Buchans area (Calon and Green 1987; Thurlow and Swanson 1987; Thurlow et al. 1992); similar kinematic relationships have been found elsewhere along strike (Zagorevski et al. 2003). Geochemical and isotopic data suggest the Buchans Group (and its northeastern equivalent, the Robert's Arm Group; Bostock 1988) represents a volcanic arc that was formed on continental basement (Swinden et al. 1997; Zagorevski et al., forthcoming). It is postulated to have formed on a sliver of continental crust that rifted off of the Dashwoods microcontinent and was emplaced outboard of the Annieopsquotch ophiolite belt and Lloyds River Complex by trench-parallel strike-slip movement (Zagorevski et al., forthcoming). Rifting of the Buchans arc at 464 Ma produced an ensimatic back-arc basin and younger arc phase, both preserved in the Red Indian Lake Group, which was subsequently thrust beneath the Buchans Group (Zagorevski et al., forth-

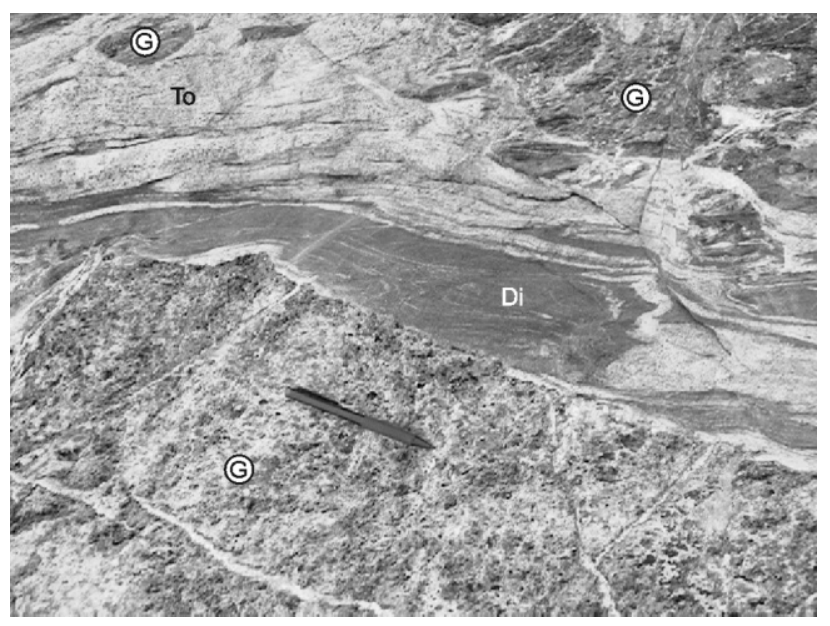

Figure 4. Sheet of highly deformed diorite $(D i)$ and tonalite $(T o)$, correlated with the Pierre's Pond suite, intrudes unfoliated gabbros $(G)$ of the Star Lake ophiolite on an island in Star Lake. Note gabbro enclaves in tonalite and large deformation contrasts between host gabbro and intrusive rocks. Pen is $15 \mathrm{~cm}$ long. coming). The Red Indian Lake Group is bounded to the southeast by the Red Indian Line, which separates it from the peri-Gondwanan arc-back-arc complexes of the Exploits Subzone (figs. 1, 2; van Staal et al. 1998; Zagorevski et al., forthcoming).

\section{Plutonic Rocks within the AAT}

Several phases of plutonic rocks intrude into the AAT and its boundaries and are concentrated around the LRFZ and the OBSZ. We will discuss their geological relationships, whole-rock geochemistry, and Nd-isotope geochemistry. Analytical techniques are described in the appendix, and detection limits and sample locations are given in Rogers (2004). Whole-rock geochemical data are listed in table 1 and $\mathrm{Nd}$-isotopic data in table 2. Note: all tables and the appendix are available in the online edition or from the Journal of Geology office.

Pierre's Pond Suite. Along the northwestern and southeastern shear zones of the LRFZ, mylonitic amphibolites of ophiolitic origin are intimately interlayered with centimeter- to meter-wide veins and sheets of foliated diorite and subordinate tonalite. In general, the amphibolites and intrusive rocks are heavily deformed. However, near Star Lake (fig. 1), such tonalite-diorite sheets have intruded outside of the LRFZ directly into ophiolitic gabbro of the Star Lake ophiolite of the Annieopsquotch ophiolite belt (fig. 4). The diorite is composed of aligned hornblende and plagioclase with accessory quartz, biotite, titanite, and oxides, whereas the tonalite is composed of plagioclase, quartz, biotite, and hornblende with accessory titanite and oxides. There is a marked contrast in deformation between the narrow zones of sheared intrusive rocks, which have foliations striking predominantly parallel to the southeastern shear zone, and the largely unfoliated host ophiolitic gabbro, which displays a partial greenschist facies metamorphic overprint (clinozoisite-actinolite-chlorite) of an earlier static amphibolite facies metamorphism. The amphibolite facies assemblage in turn largely replaced the original igneous assemblage of clinopyroxene and plagioclase. These relationships suggest that the diorite and tonalite sheets localized deformation during intrusion, with the heat of the intrusions and associated fluids producing a contact greenschist facies metamorphism in the surrounding host gabbro (Lissenberg and van Staal 2002). Given that the diorites and tonalites also intrude LRFZ amphibolites, this suggests they intruded the LRFZ syn-kinematically. We interpret these sheets as well-exposed, small-scale examples 

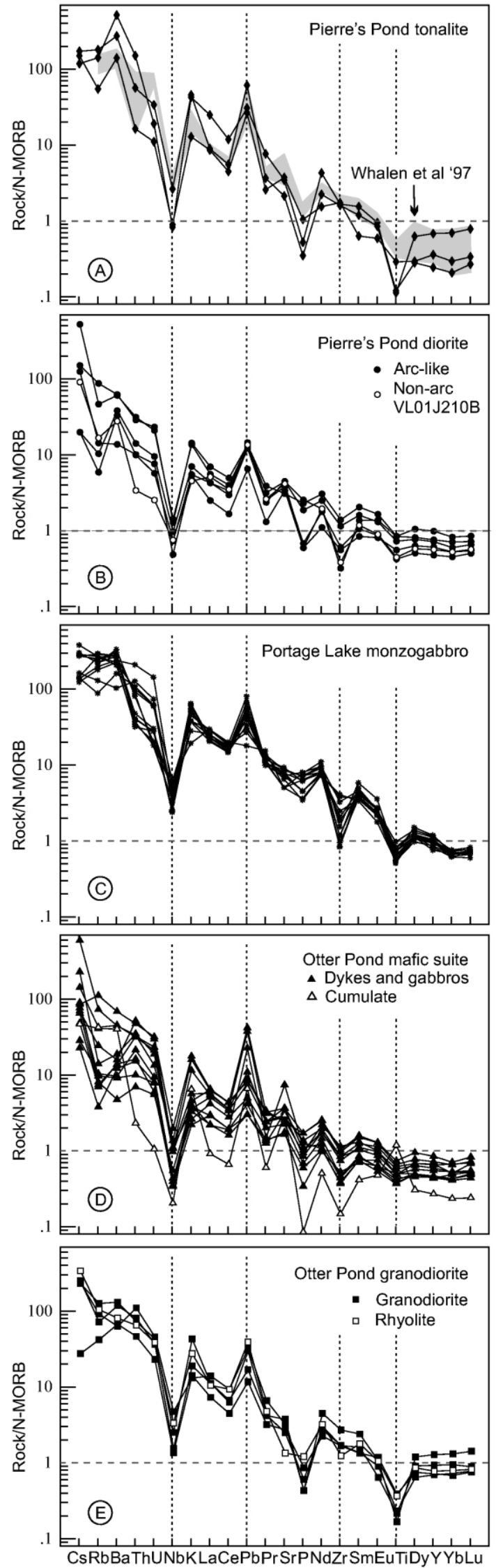

of less well-exposed larger bodies of mixed diorite and tonalite that have intruded the northwestern portion of the LRFZ and the Star Lake ophiolite at Star Lake (fig. 1) and were defined as the Pierre's Pond suite by Whalen et al. (1997).

Geochemically, the Pierre's Pond suite is composed of both arc rocks, characterized by enrichment in large ion lithophile elements (LILE) and Th over $\mathrm{Nb}$, and nonarc rocks, which lack Th enrichment with respect to $\mathrm{Nb}$ (Whalen et al. 1997). The arclike rocks were further subdivided into La-rich and La-poor groups. We analyzed several smallscale syn-kinematic diorite and tonalite sheets on Star Lake. Our tonalite analyses are similar to equivalent rocks of the Pierre's Pond suite of Whalen et al. (1997; fig. 5A), with the exception of the higher $\mathrm{K}_{2} \mathrm{O}$ content in samples VL01J225A and 238C (see table 1). This is likely related to alkali metasomatism, expressed by replacement of plagioclase by irregular patches of muscovite. The large negative $\mathrm{Nb}$ and $\mathrm{Ti}$ anomalies and the enrichment in Th and LILE (Cs, $\mathrm{Rb}, \mathrm{Ba}$ ) relative to the REE of the tonalites are typical of arc tonalite (fig. $5 A$ ). $\mathrm{La} / \mathrm{Yb}_{\mathrm{N}}$ (chondrite normalized) spans a large range (8-71), suggesting the tonalites in the LRFZ resemble both the La-rich and La-poor arclike groups of Whalen et al. (1997). The diorites show depletion in $\mathrm{Nb}, \mathrm{Zr}$, and $\mathrm{Ti}$, albeit less than the analyzed tonalites, and enrichment in LILE and Th. $\mathrm{La} / \mathrm{Yb}_{\mathrm{N}}$ ranges from 3 to 7 , typical of the La-poor arclike group of the Pierre's Pond suite (fig. 5B). Sample VL01J210B deviates from this pattern by its low $\mathrm{Th} / \mathrm{Nb}$ ratio (fig. $5 \mathrm{~B}$ ), indicative of a nonarc setting, similar to the nonarc group defined in the Pierre's Pond suite by Whalen et al. (1997). A dominantly arc origin for the tonalites and diorites is consistent with the La-Y-Nb (diorites; Cabanis and Lecolle 1989) and $\mathrm{Rb}$ versus $\mathrm{Y}+\mathrm{Nb}$ (tonalites; Pearce et al. 1984) tectonic discrimination diagrams (fig. 6). One diorite sample was analyzed for $\mathrm{Nd}$ isotopes and yielded an $\varepsilon_{\mathrm{Nd}}$ value of -5.1 (table 2), similar to values previously obtained for the Pierre's Pond suite (average $=-5.0$; Whalen et al. 1997; J. B. Whalen, unpublished data). Both geo-

Figure 5. Trace element patterns of syn-kinematic plutonic rocks in the Annieopsquotch Accretionary Tract. $A$, Pierre's Pond suite tonalites. $B$, Pierre's Pond suite diorites. $C$, Portage Lake monzogabbro. $D$, Otter Pond mafic suite and associated cumulate. E, Otter Pond granodiorite and associated rhyolite. Normalizing values from Sun and McDonough (1989). 
chemical and isotopic data thus support our interpretation that the syn-kinematic sheets belong to the Pierre's Pond suite.

Portage Lake Monzogabbro. The Portage Lake monzogabbro is herein defined as a large sheet (ca. $30 \times 5 \mathrm{~km}$ ) of foliated, generally medium-grained, K-feldspar porphyritic hornblende monzogabbro to monzonite, which occupies a central position within the LRFZ between the central and southeastern shear zones (fig. 1). Accessory phases include biotite, epidote, and titanite. K-feldspar phenocrysts typically have large aspect ratios (up to ca. 10), giving the Portage Lake monzogabbro a very distinct character (fig. 7). It comprises an early, finegrained facies, which is generally equigranular, and occurs as decimeter-sized enclaves in the coarsergrained porphyritic facies. In general, the Portage lake monzogabbro has a solid-state fabric parallel to the foliations of LRFZ amphibolites. In lowstrain zones, however, a foliation subparallel to the LRFZ is defined by the K-feldspar phenocrysts, which are locally tiled (fig. 7). The phenocrysts are enclosed in a low-strain matrix and lack pressure shadows or deformed tails, suggesting the K- feldspar foliation originated by flow in the magmatic state. A magmatic fabric subparallel to the LRFZ, along with age constraints (see below), implies the Portage Lake monzogabbro intruded synkinematically into the LRFZ. This is consistent with the presence of foliated amphibolite enclaves in a correlative monzodiorite immediately west of the Annieopsquotch ophiolite (fig. 1). This pluton is generally highly deformed with foliation parallel to the LRFZ amphibolites and has a flaser gabbrolike appearance with hornblende augen up to $1 \mathrm{~cm}$ in length within a plagioclase-K-feldspar-quartz matrix.

The Portage Lake monzogabbro is primitive, with low $\mathrm{SiO}_{2}(44.6 \%-53.5 \%)$ and high $\mathrm{MgO}+$ $\mathrm{Fe}_{2} \mathrm{O}_{3}^{*}(11.7 \%-19.6 \%)$, and has a remarkably high alkali content $(3.9 \%-7.0 \%)$, with the majority of the alkalis being $\mathrm{K}_{2} \mathrm{O}$ (average $\mathrm{K}_{2} \mathrm{O} / \mathrm{Na}_{2} \mathrm{O}=1.6$ ). The abundance of K-feldspar within the monzogabbro indicates these high $\mathrm{K}_{2} \mathrm{O}$ contents are a primary feature. The high $\mathrm{K}_{2} \mathrm{O}$ defines the Portage Lake monzogabbro as absarokite $\left(\mathrm{SiO}_{2}<52 \%\right)$ to shoshonite $\left(\mathrm{SiO}_{2}>52 \%\right.$; cf. Morrison 1980). Such
(A)

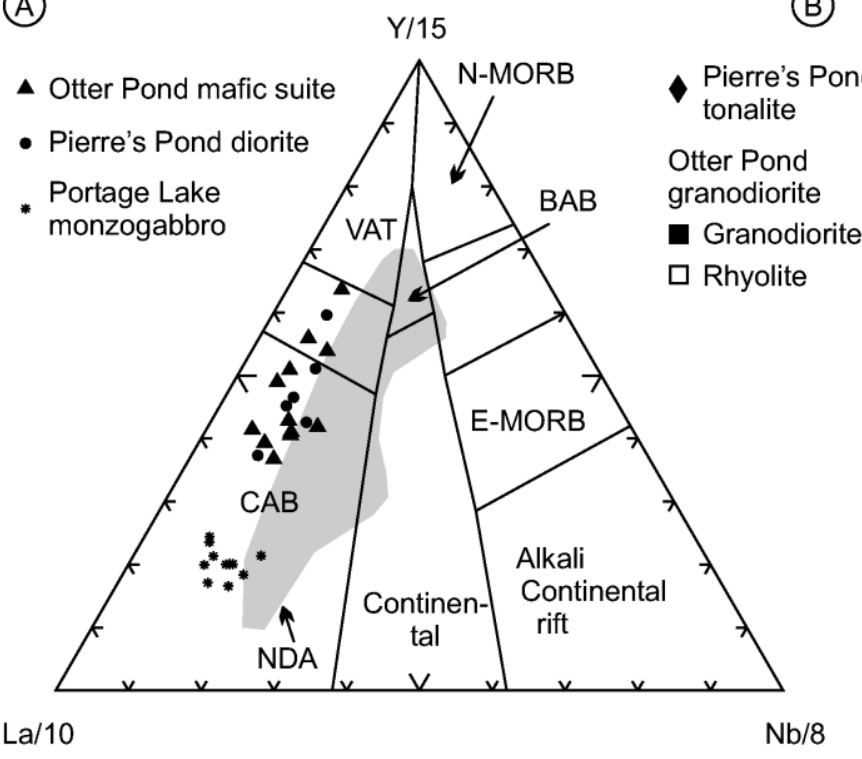

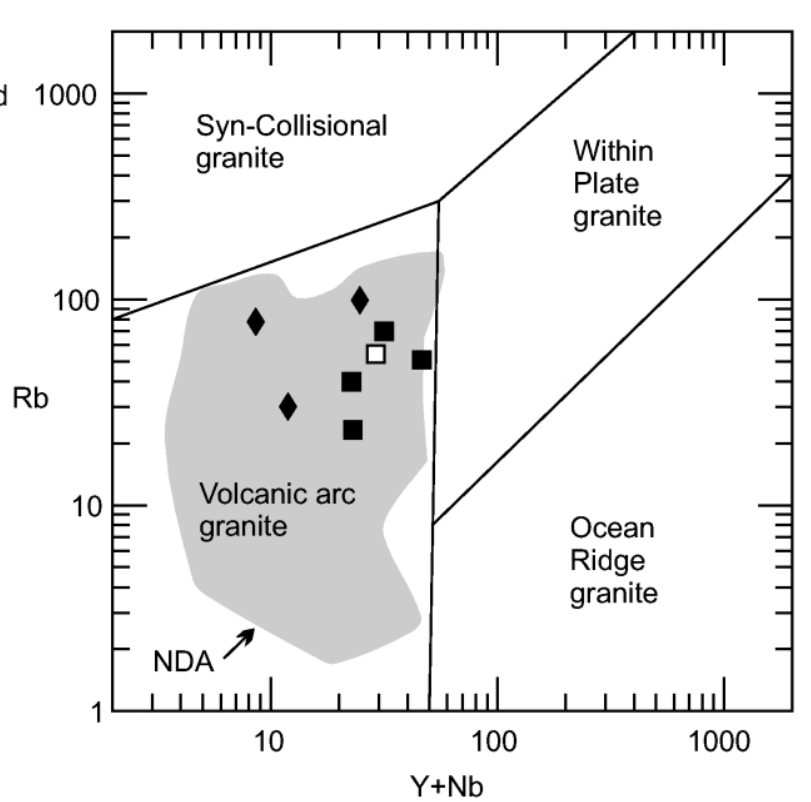

Figure 6. Tectonic discrimination diagrams for plutons within the Annieopsquotch Accretionary Tract compared with plutons of the Notre Dame Arc (NDA; shaded area). A, La-Y-Nb diagram of Cabanis and Lecolle (1989) illustrating the arc affinity of the mafic plutons (Portage Lake monzogabbro, Pierre's Pond suite diorites, Otter Pond mafic suite). $B A B=$ back-arc basin basalt; $C A B=$ calc-alkaline basalt; $E-M O R B=$ enriched midocean ridge basalt; $N-M O R B=$ normal midocean ridge basalt; $V A T=$ volcanic arc tholeiite. $B, \mathrm{Rb}$ versus $\mathrm{Nb}+\mathrm{Y}$ diagram of Pearce et al. (1984) indicating the granitoid plutons in the Annieopsquotch Accretionary Tract (Pierre's Pond suite tonalites, Otter Pond granodiorites and rhyolite) are of arc affinity. NDA data from Whalen et al. (1997) and J. B. Whalen (unpublished data). 


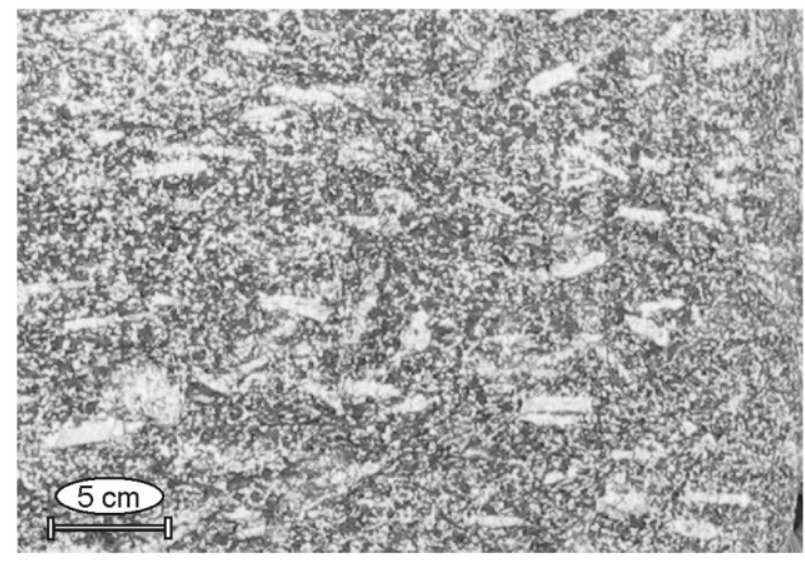

Figure 7. K-feldspar phenocrysts define a foliation in the Portage Lake monzogabbro (horizontal). Low strain in the matrix suggests the monzogabbro was deformed in part in the magmatic state.

compositions are extremely rare within the Appalachians; to our knowledge, only one other shoshonitic pluton has been reported (Pavlides et al. 1994). Harker diagrams show well-defined trends suggestive of fractionation of olivine, clinopyroxene, plagioclase, ilmenite, and apatite. The Portage Lake monzogabbro is LREE rich, with somewhat depleted HREE, leading to high $\mathrm{La} / \mathrm{Yb}_{\mathrm{N}}$ (19-24). Its trace element patterns reveal depletion in $\mathrm{Nb}, \mathrm{Ti}$, and $\mathrm{Zr}$ and marked enrichment in LILE $(\mathrm{Cs}, \mathrm{Rb}, \mathrm{Ba}, \mathrm{Th}, \mathrm{K}, \mathrm{Pb})$, indicating a strong subduction component in its petrogenesis (fig. $5 C$ ). This is consistent with the La-Y-Nb discrimination diagram (fig. $6 A$ ). The $\varepsilon_{\mathrm{Nd}}$ values of the Portage Lake monzogabbro range from -3.4 to -4.9 (table 2), suggesting crustal assimilation or recycling of an old crustal component into the mantle source. Its mafic nature (low $\mathrm{SiO}_{2}$, high $\mathrm{MgO}+\mathrm{Fe}_{2} \mathrm{O}_{3}^{*}$ )-combined with incompatible element contents higher than average upper continental crust-suggests limited crustal assimilation. We therefore interpret the Portage Lake monzogabbro to be derived from a mantle source strongly enriched in alkalis and LREE by hydrous fluids and/or melts derived from a subducted slab and overlying sediments. This is in keeping with petrogenetic models for shoshonites elsewhere (e.g., Chung et al. 2001; Sun and Stern 2001).

Otter Pond Complex. Otter Pond Mafic Suite. The Otter Pond mafic suite comprises variably deformed predominantly gabbroic-dioritic bodies that occur along the OBSZ and intrude the Annieopsquotch, Star Lake, and King George IV ophiolites as well as the Lloyds River Complex (fig. 1). The suite is generally distinct because of its hornblende porphyritic to oikocrystic nature, with the oikocrysts locally reaching a diameter of $1 \mathrm{~cm}$. In thin section, igneous tschermakitic brown amphibole oikocrysts enclose crystals of calcic plagioclase, pyroxene, and oxides. Deformed equivalents along the OBSZ locally preserve the igneous poikilitic to porphyritic texture as porphyroclastic hornblende aggregates in schists and mylonites.

Noncumulate mafic bodies of this suite have basaltic to andesitic compositions $\left(\mathrm{SiO}_{2}=47.1-56.3\right.$ $\mathrm{wt} \%, \mathrm{MgO}+\mathrm{Fe}_{2} \mathrm{O}_{3}^{*}=14.2-21.1 \mathrm{wt} \%$ ), with moderate LREE enrichment $\left(\mathrm{La} / \mathrm{Yb}_{\mathrm{N}}=2-8\right.$, average $=$ 5). LILE were likely remobilized in a postmagmatic stage, but they are consistently enriched. $\mathrm{Nb}$ is strongly depleted (average $\mathrm{Nb} / \mathrm{Th}=0.8$ ), while $\mathrm{Zr}$, $\mathrm{Hf}$, and Ti are slightly depleted (fig. $5 D$ ). The presence of amphibole oiko- and phenocrysts, calcic plagioclase, and oxides in associated cumulates indicates high water activity and oxygen fugacity. Chemistry and mineralogy of the Otter Pond mafic suite thus indicate formation in an arc environment, supported by their position in the La-Y-Nb diagram (fig. 6). The $\varepsilon_{\mathrm{Nd}}$ values of -0.9 and -1.8 for a gabbro and a mafic dike, respectively (table 2), indicate assimilation or recycling of an old crustal component into the mantle source of the suite.

Otter Pond Granodiorite Suite. The Otter pond granodiorite suite comprises several granodioritic to tonalitic bodies that intrude the Annieopsquotch

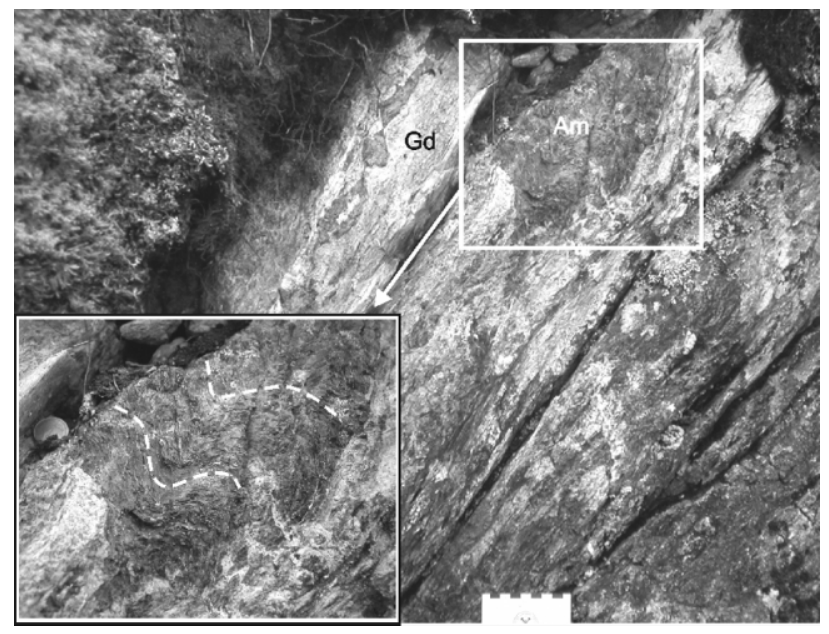

Figure 8. Small plug of Otter Pond granodiorite $(G d)$ contains enclaves of folded mylonitic amphibolite $(\mathrm{Am})$ of the Otter Brook Shear Zone (OBSZ) and is itself highly deformed, suggesting it intruded the OBSZ syn-kinematically. View toward NE. Scale card divisions are 1 $\mathrm{cm}$. 

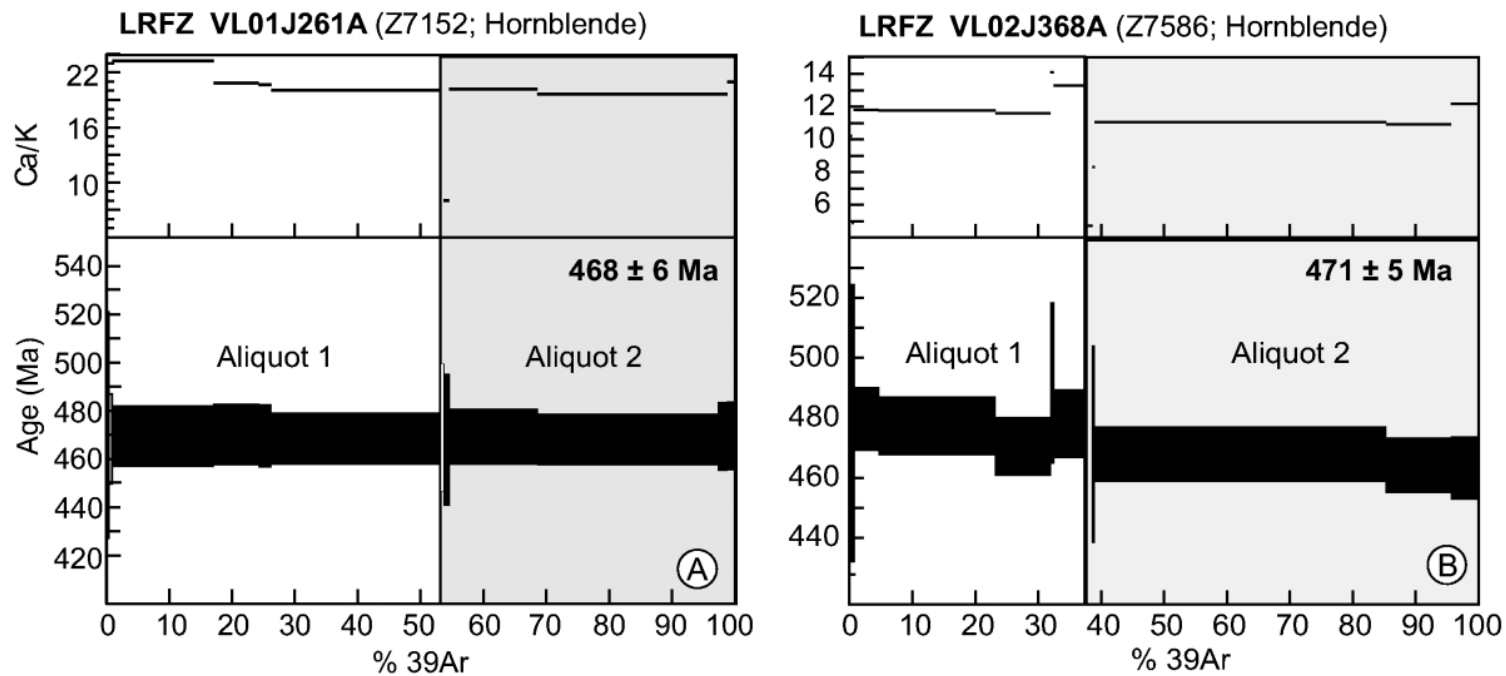

Figure 9. Results of ${ }^{40} \mathrm{Ar} /{ }^{39} \mathrm{Ar}$ hornblende geochronology. $A$, Age spectrum of ophiolite-derived amphibolite VL01J261A in Lloyds River Fault Zone (LRFZ) near the Annieopsquotch ophiolite (1 in fig. 1). B, Age spectrum of ophiolite-derived amphibolite VL02J368 in LRFZ near the Star Lake ophiolite (2 in fig. 1).

ophiolite and Lloyds River Complex as well as subordinate rhyolites. Accessory mineral phases include chloritized hornblende, chloritized biotite, and titanite. Several smaller, highly deformed, finegrained granodioritic intrusions locally cut OBSZ mylonites and have a strong foliation parallel to that within the surrounding OBSZ tectonites (fig. 8). The dikes cut the Lloyds River Complex, Annieopsquotch ophiolite, and Otter Pond mafic suite and hence also stitch the boundary between Annieopsquotch ophiolite belt and Lloyds River Complex (OBSZ). These relationships suggest the Otter Pond granodiorite suite intruded the OBSZ synkinematically (fig. 8). The suite must also postdate intrusion of the Otter Pond mafic suite. The felsic intrusions likely intruded at very shallow levels, as evidenced by the generally fine-grained nature of the larger bodies and flow banding in the associated aphanitic dikes. Chemically similar rhyolitic tuff and flows (fig. 5E), interlayered with graphitic sediment and mica schist, occur along the OBSZ and are interpreted to represent the extrusive equivalents of the shallow-level intrusions.

The Otter Pond granodiorite suite is characterized by high $\mathrm{SiO}_{2}(68.0 \%-73.2 \%)$ and alkali $(3.7 \%-$ $6.2 \%$ ) content and low to moderate $\mathrm{MgO}+\mathrm{Fe}_{2} \mathrm{O}_{3}^{*}$ $(3.0 \%-10.1 \%)$. LREE and LILE are enriched $\left(\mathrm{La} / \mathrm{Yb}_{\mathrm{N}}=6-9\right.$, average $\left.=7\right)$, while HFSE $(\mathrm{Nb}, \mathrm{Ti})$ are depleted (fig. 5E). These features suggest formation of the suite in an arc environment, consistent with its position in the $\mathrm{Rb}$ versus $\mathrm{Y}+\mathrm{Nb}$ discrimination diagram (fig. $6 B$ ). The rhyolite has a similar composition (fig. 5E) and yielded an $\varepsilon_{\mathrm{Nd}}$ value of -6.8 (table 2).

\section{Geochronology}

Analytical Procedures. Laser ${ }^{40} \mathrm{Ar} /{ }^{39} \mathrm{Ar}$ step-heating analysis was carried out at the Geological Survey of Canada (GSC), with data collection protocols after Villeneuve and MacIntyre (1997) and Villeneuve et al. (2000) and error analysis following Roddick (1988) and Scaillet (2000). Analytical data are presented in table 3 and plotted in figure 9. U-Pb TIMS and SHRIMP II analyses were conducted at the GSC. U-Pb TIMS analytical methods are outlined in Parrish et al. (1987) and Davis et al. (1997), with treatment of analytical errors after Roddick et al. (1987). SHRIMP II analyses were conducted using analytical procedures described by Stern (1997), with standards and U-Pb calibration methods following Stern and Amelin (2003). U-Pb TIMS and SHRIMP analyses are presented in tables 4 and 5, respectively, and are plotted in concordia diagrams with errors at the $2 \sigma$ level (fig. 10). Further details on the ${ }^{40} \mathrm{Ar} /{ }^{39} \mathrm{Ar}$ and U-Pb TIMS and SHRIMP analytical techniques are presented in the appendix. All of the geochronology sample locations are indicated in figure 1 and tables 3, 4, and 5.

${ }^{40} \mathrm{Ar} /{ }^{39} \mathrm{Ar}$ Geochronology. ${ }^{40} \mathrm{Ar} /{ }^{39} \mathrm{Ar}$ analyses were carried out on hornblende separates from two amphibolites that mark the LRFZ (samples 1 and 2 in fig. 1) to provide a minimum age of deformation along the LRFZ. Sample VL01J261A $(z 7152 ; 1)$ is a 

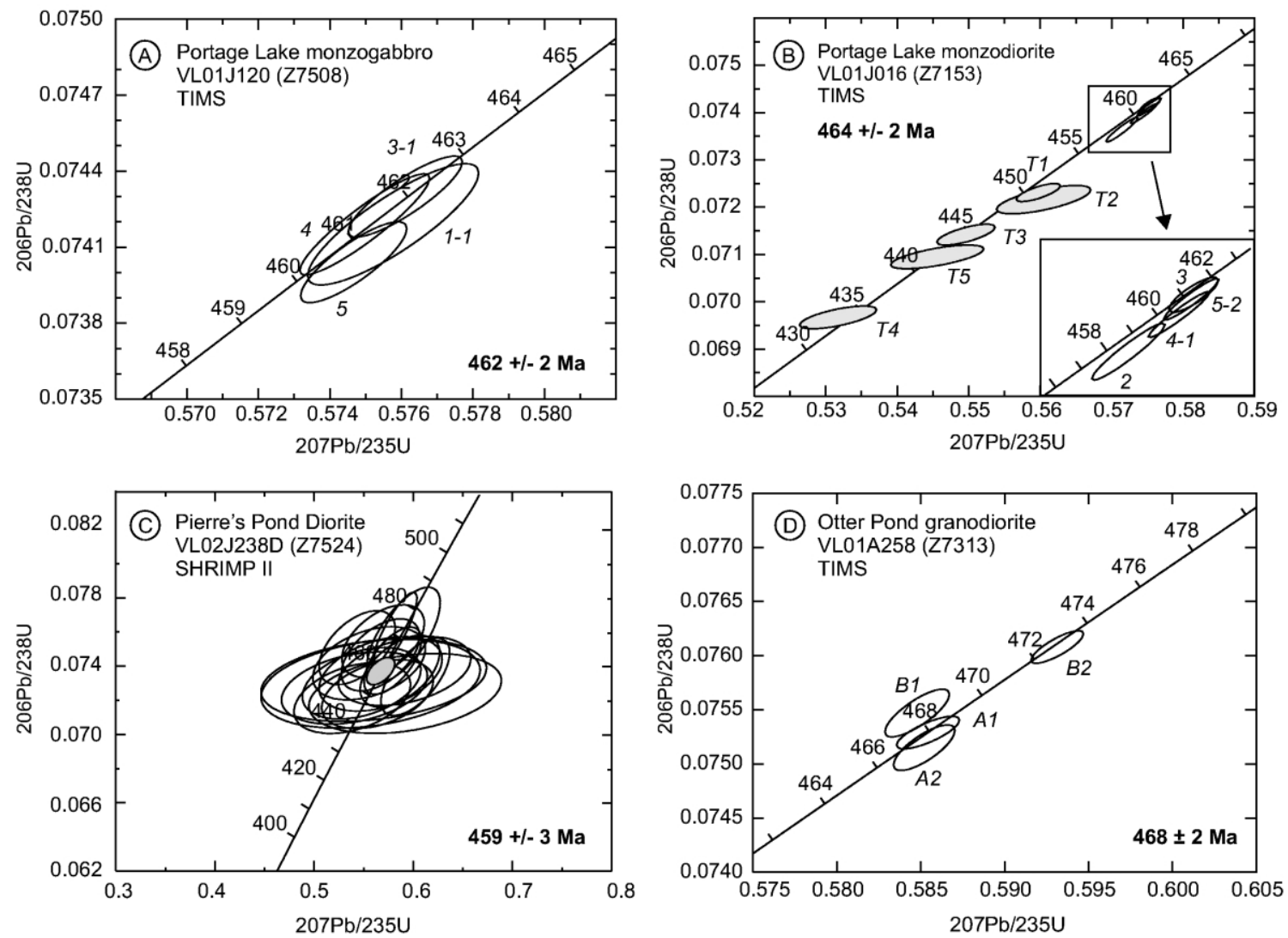

Figure 10. Concordia diagrams and ages of the Portage Lake monzogabbro $(A ; 3$ in fig. 1), Portage Lake monzodiorite $(B ; 4$ in fig. 1$)$, Pierre's Pond suite $(C ; 5$ in fig. 1$)$, and Otter Pond granodiorite $(D ; 6$ in fig. 1$)$. Italic numbers refer to fraction numbers listed in table 4 (available in the online edition or from the Journal of Geology office). Gray ellipse in diagram of VL02J238D is calculated concordia age following the method of Ludwig (1998).

strongly foliated amphibolite taken from a zone of amphibolites that defines the southeastern shear zone along the northwestern margin of the Annieopsquotch ophiolite (fig. 1). Both aliquots of this sample have fairly consistent $\mathrm{Ca} / \mathrm{K}$ ratios and yield a well-defined plateau comprising $97.4 \%$ of the total gas and defining the age of the sample to be $468 \pm 6 \mathrm{Ma}$ (table 3; fig. 9A). Sample VL02J368A $(z 7586 ; 2)$ was taken from a foliated amphibolite that marks the southeastern shear zone along the northwestern margin of the Star Lake ophiolite (fig. 1). It has a nearly constant $\mathrm{Ca} / \mathrm{K}$ ratio throughout most of the heating process, with the exception of the last steps of the two aliquots, which may indicate degassing of a second, contaminating phase. The two aliquots yield a plateau region, comprising $98.2 \%$ of the gas, which defines the age of the sample to be $471 \pm 5 \mathrm{Ma}$ (table 3 ; fig. $9 B$ ), in agreement with the age of VL01J261A. We therefore conclude that the age of ca. $470 \mathrm{Ma}$ is geologically significant and represents the age at which the amphibolites cooled below the hornblende closure temperature for argon (ca. $550^{\circ}$; Harrison 1981), providing a minimum age for ductile deformation of the LRFZ.

U/Pb Geochronology. VL01J120 (z7508)-Portage Lake Monzogabbro. A sample was collected from the main body of the Portage Lake monzogabbro, north of Lloyds Lake (3 in fig. 1). It contained abundant high-quality zircons, which were grouped into different fractions based on size and morphology (table 4). Three of the analyzed fractions are near concordant $(-0.1 \%$ to $0.5 \%$ discordant), while fraction 5 is slightly discordant $(0.8 \%)$, suggesting it has been affected by minor lead loss (fig. 10A). There is no evidence for inheritance in the sample. A weighted average of the ${ }^{207} \mathrm{~Pb} /{ }^{206} \mathrm{~Pb}$ ages of all four analyses is $462 \pm 2 \mathrm{Ma}$ $(\mathrm{MSWD}=0.9$, probability $=0.45)$. This date is interpreted to be the crystallization age of the Portage Lake monzogabbro and provides an age for synkinematic intrusion within the LRFZ.

VL01J016 (z7153)_Portage Lake Monzodiorite. 
A sample of the highly strained monzodiorite immediately west of the Annieopsquotch ophiolite, immediately south of the northwestern shear zone (4 in fig. 1), contains abundant zircon ranging in morphology from euhedral stubby prismatic grains to anhedral fragments (table 4). All of the zircon fractions analyzed are somewhat discordant $10.5 \%-$ $1.2 \%)$ and define a discordia, interpreted to result from recent lead loss. No cores have been observed, and there is no isotopic evidence for inheritance. A weighted average of the ${ }^{207} \mathrm{~Pb} /{ }^{206} \mathrm{~Pb}$ ages of all four analyses is $464 \pm 2 \mathrm{Ma}$ (MSWD $=0.5$, probability $=0.68$; fig. $10 \mathrm{~B})$, which is interpreted to be the crystallization age of the monzodiorite. This age provides a maximum age for the deformation of the monzodiorite within the LRFZ.

Four titanite fractions are $0.4 \%-3.8 \%$ discordant, and one fraction is slightly reversely discordant $(-1.9 \%$; fig. $10 B)$. The titanite analyses, which have large associated errors, define an array with ${ }^{207} \mathrm{~Pb} /$ ${ }^{206} \mathrm{~Pb}$ ages ranging between $465 \mathrm{Ma}$ and $426 \mathrm{Ma}$. This range could indicate the presence of distinct age populations within the multigrain fractions, lead loss during a younger event, or a combination thereof. Given that the host rock crystallized at 464 $\mathrm{Ma}$ (see above) and that the adjacent amphibolitegranulite facies Cormacks Lake Complex was juxtaposed along the LRFZ during rapid Early Silurian exhumation (Pehrsson et al. 2003), we postulate that the titanite population reflects a mixture of titanite formed during initial cooling of the host rock following crystallization and grains that were reset or crystallized during the ca. 430-Ma uplift of the adjacent Cormacks Lake Complex.

VL02J238D (z7524)_Pierre's Pond Suite Diorite. A sample from a highly strained syn-kinematic diorite sheet intruding ophiolitic cumulates on the shore of Star Lake (5 in fig. 1) yielded small $(50-100 \mu \mathrm{m})$, colorless to light brown zircons, which range from subhedral prismatic crystals to anhedral grain fragments with concoidal fractures. Cracks and inclusions are common, as are dark blurry cores, which likely represent inherited material. SEM imaging of the grains showed bright domains in the cores of many grains, with rims characterized by oscillatory zoning, suggesting magmatic overgrowth of inherited zircons. Some zircons were core-free, however, and were interpreted as entirely magmatic grains. A concordia age, calculated from SHRIMP analyses of magmatic grains $(n=18)$, is $458.6 \pm 3.2 \mathrm{Ma}$ (MSWD of concordance and equivalence $=1.6$, probability $=$ 0.014; fig. 10C; table 5). This age of $459 \pm 3 \mathrm{Ma}$ is interpreted as the crystallization age of the diorite and marks the age of syn-kinematic intrusion of the Pierre's Pond suite within the LRFZ. One inherited core was analyzed and yielded an age of $1961 \mathrm{Ma}$ (table 5, not plotted).

VL01A258-Otter Pond Granodiorite Suite. A sample was collected from an elongate $(500 \times 70$ $\mathrm{m})$, sheared, fine-grained granodiorite intrusion that stitches the OBSZ southeast of the Annieopsquotch ophiolite (6 in fig. 1). Two fractions of small euhedral prismatic and two fractions of small euhedral equant zircons were analyzed. Fraction A1 is concordant, and fractions $\mathrm{A} 2$ and $\mathrm{B} 1$ are slightly discordant $(0.9 \%$ and $-2.0 \%$, respectively; table 4$)$. A weighted average of the ${ }^{206} \mathrm{~Pb} /{ }^{238} \mathrm{U}$ ages of these three analyses is $468 \pm 2(\mathrm{MSWD}=2.1$, probability $=0.11$ ), which is interpreted to be the crystallization age of the granodiorite (fig. 10D). This age provides a minimum age of juxtaposition of the Annieopsquotch ophiolite belt and the Lloyds River Complex and hence a minimum age of formation of the OBSZ. Zircon fraction B2 $(n=74)$ is concordant at $473 \pm 1 \mathrm{Ma}\left({ }^{206} \mathrm{~Pb} /{ }^{238} \mathrm{U}\right)$. On the basis of its distinct morphology and concordant age, which can be distinguished from the $468 \pm 2 \mathrm{Ma}$ crystallization age, this is interpreted to be an inherited age.

\section{Discussion}

Assembly of the AAT. The data presented above impose strong time and dynamic constraints on the evolution of the AAT. The earliest tectonic activity related to assembly of the AAT is recorded by 470Ma cooling ages of hornblende from amphibolites deformed within the LRFZ, providing a minimum age on ductile deformation related to accretion of the Annieopsquotch ophiolite belt to the Dashwoods microcontinent. This suggests the belt was accreted to the Dashwoods microcontinent within $10 \mathrm{Ma}$ after its formation (480 Ma; Dunning and Krogh 1985). The Otter Pond granodiorite suite intrudes both the Annieopsquotch ophiolite belt and the structurally underlying Lloyds River Complex, and hence its age of $468 \pm 2$ Ma represents a minimum age of emplacement of the Annieopsquotch ophiolite belt above the Lloyds River Complex. The Lloyds River Complex was thus accreted within 5 $\mathrm{Ma}$ after its formation (473 Ma; Zagorevski et al., forthcoming). The overlap in minimum ages of thrusting on the LRFZ and OBSZ indicates that both shear zones are coeval and genetically related, i.e., that ophiolites of both the Annieopsquotch ophiolite belt and Lloyds River Complex were accreted to the Dashwoods microcontinent simultaneously. This is consistent with the similar kine- 
matic histories of the LRFZ and OBSZ (Lissenberg and van Staal 2002; Zagorevski and van Staal 2002).

The $473 \pm 1$-Ma inherited zircon fraction in the Otter Pond granodiorite is the same age as the Lloyds River Complex (473 Ma; Zagorevski et al., forthcoming), which it cuts, and the structurally underlying Buchans Group (473 Ma; Dunning et al. 1987). Zircons are rare within the ophiolitic Lloyds River Complex, and it is isotopically juvenile. In contrast, the ensialic Buchans Group contains abundant felsic volcanic rocks and has a nonjuvenile $\varepsilon_{\mathrm{Nd}}$ signature as a result of assimilation of crustal crust (e.g., Swinden et al. 1997). The Buchans Group is thus a more likely source of the inherited zircons, and both the Buchans Group and its basement can account for the markedly negative $\varepsilon_{\mathrm{Nd}}$ of the Otter Pond granodiorite suite $(-6.8)$. We thus infer that the granodiorite assimilated rocks of the Buchans Group and its basement during its ascent and/or was in part generated by partial melting thereof. If correct, this implies that the Buchans Group was already thrust underneath the Lloyds River Complex by $468 \mathrm{Ma}$. This is consistent with structural relationships west of the town of Buchans, where the Buchans Group was overthrust by a hot thrust sheet comprising ca. 467-Ma plutonic rocks of the Notre Dame Arc along the Hungry Mountain Thrust (Thurlow 1981; Whalen et al. 1987). Geochronological and structural data thus indicate a significant part of the AAT was assembled and accreted to the Dashwoods by $468 \mathrm{Ma}$, within $10 \mathrm{Ma}$ (Annieopsquotch ophiolite belt) and $5 \mathrm{Ma}$ (Lloyds River Complex, Buchans Group) after their intraoceanic generation.

Convergence between intraoceanic components of the AAT and the Dashwoods microcontinent likely resulted from continued collision between Laurentia and the Dashwoods microcontinent with its Notre Dame Arc. This collision had started by at least $475 \mathrm{Ma}$ (Waldron and van Staal 2001), probably initially along promontories, initiating westdirected subduction (Lissenberg et al., forthcoming a). Rollback of the subducting slab resulted in extension in the upper plate and the formation of the progressively eastward younging units of the AAT. However, continued Dashwoods-Laurentia collision caused the newly formed basins to collapse and led to underthrusting of the Annieopsquotch ophiolite belt, Lloyds River Complex, and Buchans Group underneath Dashwoods.

The subsequent tectonic history of the AAT is recorded by formation of the arc-back-arc complexes of the Red Indian Lake Group at $464 \mathrm{Ma}$, which must have occupied a position somewhat outboard of the composite Dashwoods microcon- tinent (Zagorevski et al., forthcoming). The LRFZ was still active during this time, marked by the synkinematic intrusion of the Portage Lake monzogabbro (464-462 Ma) and Pierre's Pond suite diorite (459 Ma). Final assembly of the AAT occurred when the Red Indian Lake Group was accreted to the composite Dashwoods microcontinent as a result of its collision with the peri-Gondwanan Victoria arc (van Staal et al. 1998; Zagorevski et al. 2004). The age of this collision is constrained to lie between $454 \mathrm{Ma}$ (the age of the latest volcanism of the Victoria arc; Zagorevski et al. 2004) and $450 \mathrm{Ma}$ (presence of Laurentia-derived detritus in Upper Caradoc-Ashgill sedimentary cover of the Victoria arc; e.g., McNicoll et al. 2001). Accretion-related ductile motion on the LRFZ and OBSZ had ceased by the Early Silurian, indicated by the littledeformed Lloyds Lake granite (427 $\pm 3 \mathrm{Ma}$; C. J. Lissenberg and V. J. McNicoll, unpublished data) and Boogie Lake suite $(435+6 /-3 \mathrm{Ma}$; Dunning et al. 1990), which stitch the LRFZ and OBSZ, respectively.

Source of Magmatism in the AAT. Link with the Notre Dame Arc? The plutonic rocks that intrude into the LRFZ and OBSZ have dominantly arc signatures and show $\mathrm{Nd}$-isotopic compositions indicative of involvement of an old crustal component in their petrogenesis. The plutons within the AAT share these characteristics with and are coeval with plutons of the second, slab-breakoffrelated phase of the adjacent Notre Dame Arc (469$458 \mathrm{Ma}$; van Staal et al. 2003; Whalen et al. 2003). Notre Dame Arc pluton $\varepsilon_{\mathrm{Nd}}$ values range from 2.5 to -13.5 (Whalen et al. 1997), and like the Pierre's Pond suite, they contain inherited Proterozoic zircon (Whalen et al. 1987; Dunning et al. 1989; V. J. McNicoll, unpublished data). This suggests an overall consanguineous relationship between magmatism in the AAT and the Notre Dame Arc. This is consistent with the geochronological data presented above, which indicate that the Annieopsquotch ophiolite belt, Lloyds River Complex, and Buchans Group were already accreted to the Dashwoods microcontinent prior to this magmatic phase.

The Role of Crustal Melting and Assimilation. Despite the overall similar characteristics, several notable differences exist between the plutons within the AAT and the Notre Dame Arc. First, the absarokitic to shoshonitic composition of the Portage Lake monzogabbro is unique. Only one other occurrence has been reported within the Appalachians, suggesting conditions required for shoshonite generation (highly metasomatized mantle source) and preservation (limited crustal assimila- 

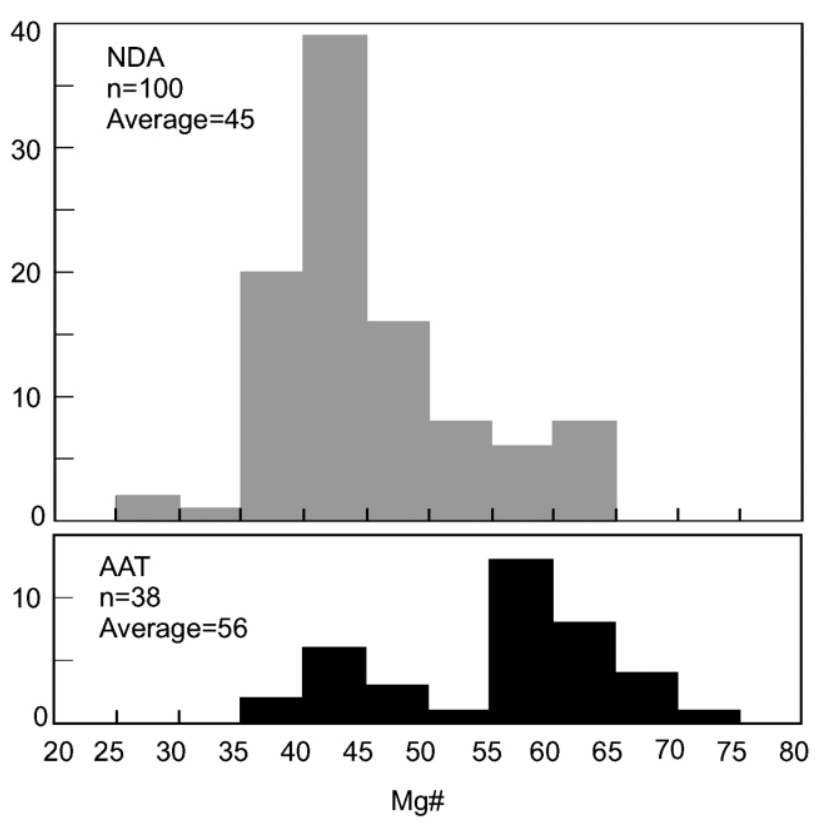

Figure 11. Histograms comparing the Mg\# of plutonic rocks of the Notre Dame Arc (NDA) and plutonic rocks within the Annieopsquotch Accretionary Tract $(A A T)$. Cumulates have been omitted. $\mathrm{Mg} \#=100 \times \mathrm{Mg} / \mathrm{Mg}+$ $\mathrm{Fe}^{2+}$, assuming $\mathrm{Fe}^{3+} / \mathrm{Fe}^{2+}=0.1$. NDA data from Whalen et al. (1997) and J. B. Whalen (unpublished data).

tion) were met only within the AAT. Second, the plutonic rocks within the AAT are volumetrically dominated by mafic compositions, with subordinate intermediate-felsic rocks (average $\mathrm{Mg \#}=56$ ), which contrasts with the dominantly evolved nature of the Notre Dame Arc (average $\mathrm{Mg} \#=45$; fig. 11). In addition, the Otter Pond mafic suite and Portage Lake monzogabbro are as primitive or more primitive than the most primitive Notre Dame Arc suites. The cause of the more mafic nature of the plutons within the AAT is unlikely to be source related, since they are thought to be consanguineous with the Notre Dame Arc plutons, and the Portage Lake monzogabbro was likely sourced by mantle of, or mantle derived from, the Dashwoods microcontinent (i.e., the same mantle source by which the Notre Dame Arc was underlain; see below). In contrast, we suggest the dominantly mafic character of the Portage Lake monzogabbro, Otter Pond mafic suite, and part of the Pierre's Pond suite is caused by the tectonic environment in which they were emplaced. First, the AAT likely comprised dominantly thin, ophiolitic crust. Second, the close spatial association between the plutons and the LRFZ plus OBSZ indicates the plutons ascended along active large-scale shear zones, signif- icantly facilitating magma transport, thereby limiting crustal assimilation.

The bimodal distribution of plutons within the AAT, with dominant mafic and subordinate evolved phases, reflects different petrogenetic processes between the Portage Lake monzogabbro and Otter Pond mafic suite on the one hand and the Otter Pond granodiorite and Pierre's Pond suite tonalites on the other hand. The Pierre's Pond diorites appear to have characteristics of both groups. The Portage Lake monzogabbro and Otter Pond mafic suite have high compatible element contents $(\mathrm{MgO}, \mathrm{Cr}, \mathrm{Ni})$, suggesting limited crustal assimilation and preservation of a significant mantlederived component. In contrast, the magnitude of the negative $\varepsilon_{\mathrm{Nd}}$ values (up to -6.8 ) and the evolved nature of the Otter Pond granodiorite suite and Pierre's Pond suite tonalites, as well as the presence of inherited Paleoproterozoic zircons in the Pierre's Pond Suite diorite, suggest that partial melting and/ or assimilation of continental crust was a major process in formation of these plutons. However, the crustal component of the plutons within the AAT cannot be derived from crust of the Dashwoods microcontinent, since both field and seismic data indicate that the AAT structurally underlies Dashwoods (fig. 2). The 473-Ma inherited zircons in the Otter Pond granodiorite and structural relationships in the Buchans area are consistent with accretion of the Buchans Group, and by inference its continental basement, to the Dashwoods microcontinent prior to magmatism in the AAT. We thus infer that the AAT was underlain by the continental basement of the Buchans Group during generation of the plutonic rocks in the AAT. This is consistent with seismic interpretations, which suggest that the thrust slices that contain the Buchans Group are present underneath the entire AAT and cut out the Annieopsquotch ophiolite belt at depth (fig. 2; van der Velden et al. 2004).

The Source of the Portage Lake Monzogabbro. The strong enrichment in LREE and LILE and negative $\varepsilon_{\mathrm{Nd}}$ of the Portage Lake monzogabbro, combined with its primitive nature, require a mantle source extensively enriched by an old crustal component. Given the marked absence of sediments within the AAT, it is unlikely that the enrichment is caused solely by subduction of continent-derived material. In contrast, we propose that the Portage Lake monzogabbro taps old subcontinental lithospheric mantle of the Dashwoods microcontinent or its derivative, the basement to the Buchans arc. This is analogous to recent shoshonites and associated high-K magmas in the eastern Sunda arc and Taiwan, which were produced by melting of en- 
riched subcontinental lithosphere following arccontinent collision (Varne 1985; Wang et al. 2004). In the Sunda arc, there is a spatial relationship between K-enrichment, concurrent with decreasing $\varepsilon_{\mathrm{Nd}}$, and proximity to the advancing Australian plate. Arc-continent collision has caused the arc to tap a dominantly subcontinental Australian mantle source in the east, yielding shoshonites, whereas to the west where the collision has not yet occurred, the high-K signature decreases, and calcalkaline and transitional arc tholeiites erupt (Varne 1985). The intrusion of the Portage Lake monzogabbro occurred ca. $5 \mathrm{Ma}$ after the Buchans arcDashwoods microcontinent collision, suggesting it was generated in a tectonic setting very similar to the Sunda and Taiwan shoshonites. Limited crustal assimilation within the AAT allowed the lithospheric mantle signature to be largely retained, leading to the unique geochemical character of the Portage Lake monzogabbro.

Accretionary Tectonics. The AAT records a complicated history of generation and accretion of several intraoceanic elements within a short time span. Two geochemically and geochronologically distinct suprasubduction zone ophiolites, the Annieopsquotch ophiolite belt and the Lloyds River Complex, were formed within a time span of $7 \mathrm{Ma}$ (Zagorevski et al., forthcoming) above a westdipping subduction zone. The formation of the Lloyds River Complex was related to rifting of the coeval Buchans arc off of the Dashwoods microcontinent, combined with trench-parallel movement (Zagorevski et al., forthcoming). The Buchans arc in turn rifted shortly $(9 \mathrm{Ma})$ after its formation to yield the Red Indian Lake arc and associated back-arc (Zagorevski et al., forthcoming). The Red Indian Lake arc retained its intraoceanic position for ca. $10 \mathrm{Ma}$, when it collided with the PeriGondwanan Victoria Lake arc along the Red Indian Line. The accretion of the units to the Dashwoods microcontinent was oblique and coeval with the intrusion of several plutons. The observed complexities, notably the rapid generation and migration of arc-back-arc igneous complexes, the intrusion of plutons into accretionary complexes, and the abundance of strike-slip movements, are reminiscent of the current southwest Pacific (e.g., Hall 2002) as well as other Paleozoic (e.g., Kunlun; Xiao et al. 2003) and Meso-Cenozoic orogens (e.g., Kamchatka; Konstantinovskaia 2001) and illustrate the dynamic nature of accretionary margins.

However, the virtual absence of sediments and the importance of recycled continental basement in the AAT (basement of Buchans and Red Indian Lake arcs) contrast with other major accretionary orogens, which are dominated by large, dominantly sedimentary accretionary complexes, intruded by arc plutons as a result of progressive retreat of the subducting slab (e.g., Sengör and Natal'in 1996). These arc plutons are generally isotopically juvenile, signaling an important depleted mantle component in their petrogenesis (Chen et al. 2000 and references therein). Such accretionary orogens show little evidence of arc rifting or presence of rifted continental slivers and are characterized by long-lived subduction-accretion in the forearc, leading to the formation of large sedimentary prisms (Sengör and Natal'in 1996), similar to the Aleutian accretionary complex (Moore et al. 1991). In contrast, the AAT results from repeated rifting and rapid accretion of slivers of the Dashwoods microcontinent, their overlying arcs, and intervening basins. The short life span of these basins, as well as the submarine nature of the Buchans and Red Indian Lake arcs, limited sediment influx and hence forearc accretion. Plutons intruding the AAT are unrelated to the west-dipping subduction of Iapetus oceanic lithosphere but instead formed in response to slab breakoff of the oceanic portion of the east-dipping Humber Seaway slab. Plutons in the AAT thus tapped not only a subarc mantle source but also an enriched lithospheric mantle and crustal source, leading to isotopically evolved signatures. The AAT thus records a greater ratio of recycled crustal material over newly added mantlederived material than most other accretionary orogens.

\section{Conclusion}

The AAT in Newfoundland is a well-preserved example of an Early Paleozoic accretionary complex, which formed by the accretion of several arc sequences and oceanic crust to the composite Laurentian margin. It preserves a record of ca. 30 million years of west-directed subduction beneath Laurentia, providing a unique view of the tectonic processes during the Early-Middle Ordovician closure of Iapetus. This record is poorly preserved elsewhere in the northern Appalachians, mainly because of the presence of extensive Siluro-Devonian cover sequences (van Staal et al. 1998). Assembly of the AAT is recorded by shear zones that separate distinct units and syn-kinematic plutonic suites within those shear zones. Age constraints suggest that the various units of the AAT were accreted to the Laurentian margin 5-10 million years after their formation.

Growth of the Appalachian Laurentian margin occurred mainly because of the repeated accretion 
of oceanic crust and the addition of melts generated in both lithospheric and sub-arc mantle. However, recycling of continental crust in the form of continental slivers that formed basement to the arc sequences was also an important process within the AAT. The involvement of this basement, combined with an enriched lithospheric mantle, caused the syn-kinematic plutons in the AAT to be isotopically evolved. Sediment influx during formation of the AAT apparently was minor, significantly limiting the role of forearc accretion.

The data presented in this article indicate that the tectono-magmatic processes in Iapetus operated over very short timescales. In addition, it presents a record of dynamic interaction between extension due to subduction rollback and evidenced by the formation of marginal basins and arc-trench migration and episodic compression in the abandoned back-arc region, leading to rapid closure and accretion of the remnant arc phases and marginal basins.

The role of strike-slip tectonics, particularly the movement of forearc continental slivers, was probably significant during the tectonic evolution of the AAT, although its exact role in the development of the AAT remains to be established. The tectonic complexities along the Early Palaeozoic Laurentian margin were thus similar to those operating at present in the southwest Pacific. In general, the nature of accretionary tectonics thus appears to have remained unchanged throughout the Phanerozoic.

\section{A C K N O W LE D G M EN T S}

This research is funded by a scholarship from the faculty of graduate and postdoctoral studies, University of Ottawa, to C. J. Lissenberg, a Natural Sciences and Engineering Research Council (NSERC) postgraduate scholarship and Natural Resources Canada Earth Sciences Sector postgraduate scholarship supplement to A. Zagorevski, and an NSERC grant to C. R. van Staal in his position as adjunct professor at the University of Ottawa. We would like to thank N. Rogers, S. Pehrsson, and A. Brem for discussions of Newfoundland geology and D. Portsmouth, M. McGillen, A. Dumoulin, and S. Cain for able field assistance. Comments from $\mathrm{T}$. Skulski, J. Hibbard, and two anonymous reviewers greatly improved the manuscript. J. Peressini, D. Bellerive, and C. Lafontaine are acknowledged for their assistance in the Geochronology lab. This is Geological Survey of Canada contribution 2004275.

\section{REFERENCES CITED}

Bostock, H. H. 1988. Geology and petrochemistry of the Ordovician volcano-plutonic Robert's Arm group, Notre Dame Bay, Newfoundland. Geol. Surv. Can. Bull. $369,84 \mathrm{p}$.

Cabanis, B., and Lecolle, M. 1989. Le diagramme La/10$\mathrm{Y} / 15-\mathrm{Nb} / 8$ : un outil pour la discrimination des series volcaniques et la mise en evidence des processus de melange et/ou de contamination crustale. C. R. Acad. Sci. Ser. II Mec. Phys. Chim. Sci. Univers Sci. Terre 309-20:2023-2029.

Calon, T. J., and Green, F. K. 1987. Preliminary results of a detailed structural analysis of the Buchans Mine area. In Kirkham, R. V., ed. Buchans geology, Newfoundland. Geol. Surv. Can. Pap. 86-24:273-288.

Chen, B.; Jahn, B.; Wilde, S.; and Xu, B. 2000. Two contrasting Paleozoic magmatic belts in northern Inner Mongolia, China: petrogenesis and tectonic implications. Tectonophysics 328:157-182.

Chung, S.-L.; Wang, K.-L.; Crawford, A. J.; Kamenetsky, V. S.; Chen, H.-H.; Lan, C.-Y.; and Chen, C. H. 2001. High-Mg potassic rocks from Taiwan: implications for the genesis of orogenic potassic lavas. Lithos 59:153170.

Davis, W. J.; McNicoll, V. J.; Bellerive, D. R.; Santowski, K.; and Scott, D. J. 1997. Modified chemical procedures for the extraction and purification of uranium from titanite, allanite and rutile in the Geochronology Laboratory, Geological Survey of Canada. Radiogenic
Age and Isotopic Studies, Rep. 10. Geol. Surv. Can. Curr. Res. 1997-F:33-35.

Dunning, G. R.; Kean, B. F.; Thurlow, J. G.; and Swinden, H. S. 1987. Geochronology of the Buchans, Roberts Arm, and Victoria Lake groups and Mansfield Cove Complex, Newfoundland. Can. J. Earth Sci. 24:11751184.

Dunning, G. R., and Krogh, T. E. 1985. Geochronology of ophiolites in the Newfoundland Appalachians. Can. J. Earth Sci. 22:1659-1670.

Dunning, G. R.; O’Brien, S. J.; Colman-Sadd, S. P.; Blackwood, R. F.; Dickson, W. L.; O'Neill, P. P.; and Krogh, T. E. 1990. Silurian orogeny in the Newfoundland Appalachians. J. Geol. 98:895-913.

Dunning, G. R.; Wilton, D. H. C.; and Herd, R. K. 1989. Geology, geochemistry and geochronology of a Taconic batholith, southwestern Newfoundland. Trans. R. Soc. Edinb. 80:159-168.

Hall, R. 2002. Cenozoic geological and plate tectonic evolution of SE Asia and the SW Pacific: computer-based reconstructions, model and animations. J. Asian Earth Sci. 20:353-431.

Harrison, T. M. 1981. Diffusion of ${ }^{40} \mathrm{Ar}$ in hornblende. Contrib. Mineral. Petrol. 78:324-331.

Konstantinovskaia, E. A. 2001. Arc-continent collision and subduction reversal in the Cenozoic evolution of the Northwest Pacific: an example from Kamchatka (NE Russia). Tectonophysics 333:75-94. 
Krogh, T. E. 1982. Improved accuracy of U-Pb ages by creation of more concordant systems using an air abrasion technique. Geochim. Cosmochim. Acta 46:637649.

Lissenberg, C. J.; Bédard, J. H.; van Staal, C. R.; and Zagorevski, A. Forthcoming $a$. Geochemical constraints on the origin of the Annieopsquotch ophiolite belt, southwest Newfoundland. Geol. Soc. Am. Bull.

Lissenberg, C. J., and van Staal, C. R. 2002. The relationships between the Annieopsquotch ophiolite belt, the Dashwoods Block and the Notre Dame Arc in southwestern Newfoundland. Curr. Res., Newfoundland Dep. Energy and Mines, Geol. Surv. Rep. 02-1: $145-153$.

Lissenberg, C. J.; Zagorevski, A.; Rogers, N.; van Staal, C. R.; and Whalen, J. B. Forthcoming b. Geology, Star Lake, Newfoundland, 12A/11. Geol. Surv. Can. Open File 1669, scale $1: 50,000$.

Ludwig, K. R. 1998. On the treatment of concordant uranium-lead ages. Geochim. Cosmochim. Acta 62: 665-676.

McNicoll, V. J.; van Staal, C. R.; and Waldron, J. W. F. 2001. Accretionary history of the northern Appalachians: SHRIMP study of Ordovician-Silurian syntectonic sediments in the Canadian Appalachians. Geol. Assoc. Can. Mineral. Soc. Can. Joint Annu. Meeting Abstr. 26:100-101.

Moore, J. C.; Diebold, J.; Fisher, M. A.; Sample, J.; Brocher, T.; Talwani, M.; Ewing, J.; von Huene, R.; Rowe, C.; Stone, D.; Stevens, C.; and Sawyer, D. 1991. EDGE deep seismic reflection transect of the eastern Aleutian arc-trench layered lower crust reveals underplating and continental growth. Geology 19:420 424.

Morrison, G. W. 1980. Characteristics and tectonic setting of the shoshonite rock association. Lithos 13:97108.

Parrish, R. R.; Roddick, J. C.; Loveridge, W. D.; and Sullivan, R. W. 1987. Uranium-lead analytical techniques at the Geochronology Laboratory, Geological Survey of Canada. Radiogenic Age and Isotopic Studies, Rep. 1. Geol. Surv. Can. Pap. 87-2:3-7.

Pavlides, L.; Arth, J. G.; Sutter, J. F.; Stern, T. W.; and Cortesini, H. 1994. Early Paleozoic alkalic and calcalkalic plutonism and associated contact metamorphism, central Virginia Piedmont. U.S. Geol. Surv. Prof. Pap., 147 p.

Pearce, J. A.; Harris, N. B. W.; and Tindle, A. G. 1984. Trace element discrimination diagrams for the tectonic interpretation of granitic rocks. J. Petrol. 25:956983.

Pehrsson, S. J.; van Staal, C. R.; Herd, R. K.; and McNicoll, V. 2003. The Cormacks Lake Complex, Dashwoods Subzone: a window into the deeper levels of the Notre Dame Arc. Curr. Res., Newfoundland Dep. Energy and Mines, Geol. Surv. Rep. 03-1:115-125.

Roddick, J. C. 1988. The assessment of errors in ${ }^{40} \mathrm{Ar} /$ ${ }^{39}$ Ar dating. Radiogenic Age and Isotopic Studies, Rep. 2. Geol. Surv. Can. Pap. 88-2:7-16.

Roddick, J. C.; Loveridge, W. D.; and Parrish, R. R. 1987.
Precise U-Pb dating of zircon at the sub-nanogram $\mathrm{Pb}$ level. Chem. Geol. 66:111-121.

Rogers, N. 2004. Geochemical database, Red Indian Line project, Central Newfoundland. Geol. Surv. Can. Open File 4605.

Scaillet, S. 2000. Numerical error analysis in ${ }^{40} \mathrm{Ar} /{ }^{39} \mathrm{Ar}$ dating. Chem. Geol. 162:269-298.

Sengör, A. M. C., and Natal'in, B. A. 1996. Turkic-type orogeny and its role in the making of the continental crust. Annu. Rev. Earth Planet. Sci. 24:263-337.

Stern, R. A. 1997. The GSC sensitive high resolution ion microprobe (SHRIMP): analytical techniques of zircon $\mathrm{U}-\mathrm{Pb}$-Th age determinations and performance evaluation. Radiogenic Age and Isotopic Studies, Rep. 10. Geol. Surv. Can. Curr. Res. 1997-F:1-31.

Stern, R. A., and Amelin, Y. 2003. Assessment of errors in SIMS zircon U-Pb geochronology using a natural zircon standard and NIST SRM 610 glass. Chem. Geol. 197:111-146.

Sun, C.-H., and Stern, R. J. 2001. Genesis of Mariana shoshonites: contribution of the subduction component. J. Geophys. Res. 106-B1:589-608.

Sun, S.-S., and McDonough, W. F. 1989. Chemical and isotopic systematics of oceanic basalts: implications for mantle compositions and processes. In Saunders, A. D., and Norry, M. J., eds. Magmatism in the ocean basins. Geol. Soc. Lond. Spec. Publ. 42:313-345.

Swinden, H. S.; Jenner, G. A.; and Szybinski, Z. A. 1997. Magmatic and tectonic evolution of the CambrianOrdovician Laurentian margin of Iapetus: geochemical and isotopic constraints from the Notre Dame Subzone, Newfoundland. In Sinha, A. K.; Whalen, J. B.; and Hogan, J. P., eds. The nature of magmatism in the Appalachian Orogen. Geol. Soc. Am. Mem. 191:337365.

Thurlow, J. G. 1981. The Buchans group: its stratigraphic and structural setting, In Swanson, E. A.; Strong, D. F.; and Thurlow, J. G., eds. The Buchans orebodies; fifty years of geology and mining. Geol. Assoc. Can. Spec. Pap. 22:79-90.

Thurlow, J. G.; Spencer, C. P.; Boerner, D. E.; Reed, L. E.; and Wright, J. A. 1992. Geological interpretation of a high resolution reflection seismic survey at the Buchans mine, Newfoundland. Can. J. Earth Sci. 29:20222037.

Thurlow, J. G., and Swanson, E. A. 1987. Stratigraphy and structure of the Buchans Group. In Kirkham, R. V., ed. Buchans Geology, Newfoundland. Geol. Surv. Can. Pap. 86-24:35-46.

van der Velden, A. J.; van Staal, C. R.,; and Cook, F. A. 2004. Paleosubduction of Ganderia beneath Laurentia: a reprocessed lithoprobe seismic reflection survey of the Newfoundland Appalachians. Geol. Soc. Am. Bull. 166:1485-1498.

van Staal, C. R.; Dewey, J. F.; Mac Niocaill, C.; and McKerrow, W. S. 1998. The Cambrian-Silurian tectonic evolution of the northern Appalachians and British Caledonides: history of a complex, west and southwest Pacific type segment of Iapetus. In Blundell, D. 
J., and Scott, A. C., eds. Lyell: the past is the key to the present. Geol. Soc. Lond. Spec. Publ. 143:199-242. van Staal, C. R.; Lissenberg, C. J.; Pehrsson, S. J.; Zagorevski, A.; Valverde-Vaquero, P.; Herd, R. K.; McNicoll, V.; and Whalen, J. Forthcoming a. Geology, Puddle Pond, Newfoundland, 12A/05. Geol. Surv. Can. Open File 1664, scale $1: 50,000$.

van Staal, C. R.; Valverde-Vaquero, P.; Zagorevski, A.; Boutsma, S.; Pehrsson, S.; van Noorden, M.; and McNicoll, V. Forthcoming b. Geology, King George IV Lake, Newfoundland (NTS 12A/04). Geol. Surv. Can. Open File 1665, scale $1: 50,000$.

van Staal, C. R.; Whalen, J. B.; Pehrsson, S. J.; and McNicoll, V. J. 2003. Tectonic evolution of the Notre Dame magmatic arc, Newfoundland Appalachians. Eos Trans. AGU 84(46), Fall Meet. Suppl., Abstract V41A-06.

van Staal, C. R.; Zagorevski, A.; Valverde-Vaquero, P.; Rogers. N.; and Lissenberg, C. J. Forthcoming $c$. Geology, Victoria Lake, Newfoundland, 12A/06. Geol. Surv. Can. Open File 1667, scale 1 :50,000.

Varne, R. 1985. Ancient subcontinental mantle: a source for K-rich orogenic volcanics. Geology 13:405-408.

Villeneuve, M. E., and MacIntyre, D. G. 1997. Laser ${ }^{40} \mathrm{Ar} /$ ${ }^{39} \mathrm{Ar}$ ages of the Babine porphyries and Newman Volcanics, Fulton Lake map area, west-central British Columbia. Radiogenic Age and Isotopic Studies, Rep. 10. Geol. Surv. Can. Curr. Res. 1997-F:131-139.

Villeneuve, M. E.; Sandeman, H. A.; and Davis, W. J. 2000. A method for the intercalibration of U-Th-Pb and ${ }^{40} \mathrm{Ar} /{ }^{39} \mathrm{Ar}$ ages in the Phanerozoic. Geochim. Cosmochim. Acta 64:4017-4030.

Waldron, J. W. F., and van Staal, C. R. 2001. Taconian orogeny and the accretion of the Dashwoods block: a peri-Laurentian microcontinent in the Iapetus ocean. Geology 29:811-814.

Wang, K.-L.; Chung, S.-L.; O'Reilly, S. Y.; Sun, S.-S.; Shinjo, R.; and Chen, C.-H. 2004. Geochemical constraints for the genesis of post-collisional magmatism and the geodynamic evolution of the northern Taiwan region. J. Petrol. 45-5:975-1011.

Whalen, J. B.; Currie, K. L.; and van Breemen, O. 1987. Episodic Ordovician-Silurian plutonism in the Topsails igneous terrane, western Newfoundland. Trans. R. Soc. Edinb. 78:17-28.

Whalen, J. B.; Jenner, G. A.; Longstaffe, F. J.; Gariepy, C.; and Fryer, B. J. 1997. Implications of granitoid geochemical and isotopic $(\mathrm{Nd}, \mathrm{O}, \mathrm{Pb})$ data from the Cambrian-Ordovician Notre Dame arc for the evo- lution of the Central Mobile belt, Newfoundland Appalachians. In Sinha, A. K.; Whalen, J. B.; and Hogan, J. P., eds. The nature of magmatism in the Appalachian Orogen. Geol. Soc. Am. Mem. 191:367-395.

Whalen, J. B.; McNicoll, V. J.; van Staal, C. R.; and Pehrsson, S. J. 2003. Plutonic rock geochemical and isotopic evidence for a transition from arc (c. 489-435 Ma) to within-plate (c. $430 \mathrm{Ma}$ ) magmatism within the Notre Dame arc. Geol. Soc. Am. Abstr. Programs 35-3:33.

Williams, H. 1979. Appalachian orogen in Canada. Can. J. Earth Sci. 16:792-807.

- 1995. Temporal and spatial divisions. In Geology of the Appalachian-Caledonian Orogen in Canada and Greenland: Ottawa. Geol. Surv. Can. Geol. Can. 6:2344.

Williams, H.; Colman-Sadd, S. P.; and Swinden, H. S. 1988. Tectonic-stratigraphic subdivision of central Newfoundland. Current Research, Geological Survey of Canada, paper 88-1B:91-98.

Williams, H., and Hatcher, R. D. 1983. Appalachian suspect terranes. In Hatcher, R. D.; Williams, H.; and Zietz, I., eds. The tectonics and geophysics of mountain chains. Geol. Soc. Am. Mem. 158:33-53.

Xiao, W.-J.; Han, F.; Windley, B. F.; Yuan, C.; Zhou, H.; and Li, J. 2003. Multiple accretionary orogenesis and episodic continental growth of continents: insights from the western Kunlun range, central Asia. Int. Geol. Rev. 45:303-328.

Zagorevski, A.; Lissenberg, C. J.; van Staal, C. R.; McNicoll, V.; and Rogers, N. 2003. Tectonic history of the Annieopsquotch Accretionary Tract. Geol. Soc. Am. Abstr. Program 35-3:34.

Zagorevski, A.; Rogers, N.; van Staal, C. R.; McNicoll, V.; Lissenberg, C. J.; Valverde-Vaquero, P. Forthcoming. Lower to Middle Ordovician evolution of periLaurentian arc and back-arc complexes in the Iapetus: constraints from the Annieopsquotch Accretionary Tract, Central Newfoundland. Geol. Soc. Am. Bull.

Zagorevski, A., and van Staal, C. R. 2002. Structures associated with the Red Indian Line in southwestern Newfoundland. Curr. Res., Newfoundland Dep. Energy and Mines, Geol. Surv. Rep. 02-1:211-218.

Zagorevski, A.; van Staal, C. R.; McNicoll, V.; and Rogers, N. 2004. Pat's Pond and Wigwam Brook Groups: record of episodic per-Gondwanan Upper CambrianCaradoc Island arc activity in the Exploits Subzone of Central Newfoundland. Geol. Soc. Am. Abstr. Program 36-2:129. 